This dissertation has been

$66-1797$

microfilmed exactly as received

KING, James Sargent, 1938-

A COMPARATIVE INVESTIGATION OF NEUROGLIA IN REPRESENTATIVE VERTEBRATES: A SILVER CARBONATE STUDY.

The Ohio State University, Ph.D., 1965

Anatomy

University Microfilms, Inc., Ann Arbor, Michigan 
A COMPARATIVE INVESTIGATION OF NEUBOALIA IN FEPRESEMTATIVE

VERTEBRATES: A SIIVER CARBONATE STUDY

DISSERTATION

Presented in Partial Fulfiliment of the Requirenents for the Degree Doctor of Philosophy in the Graduate

School of The Ohio State University

By

James Sargent King, B.S., M.Sc.

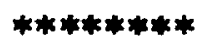

- ...

The Ohio State Univeraity

1965

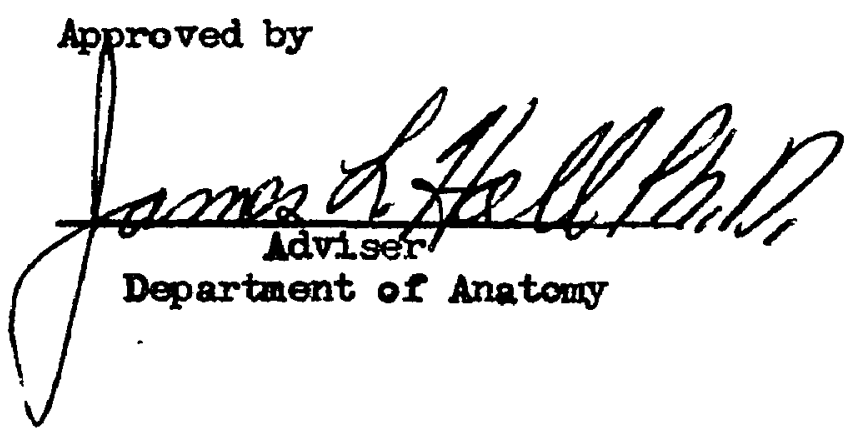




\section{ACANOWL EDDGMENTS}

The author wishes to thank the following people: Miss Selly O'Ne11. for technical assistance; Mr. Vernon Cady. for atd in the preparation of photographic plates; and Mr. Thomas Biggert, for the translation of literature. The author also wishes to acknorledge the valuable counsel and assistance of Dr. Leopold I1ss, Department of Pathology; and especially his adviser. Dr. James L. Hall of the Anatomy Department, School of Medicine, The Ohio State Univeratty. for help in the preparation of this dissertation. 
VITA

Novenber 19, 1938 . . Born - Palnesvilize, Ohto

1960 ...... B.S. Taylor University, Upland, Indiana

1960-1961 . . . . Teacher, Public Schools, Springfleld, Ohto

1961-1963 . . . . Graduate assistant, Department of Anatony, The Ohio State University. Columbus, Ohio

1962 ....... M.Sc.. The Ohio State Untrersity, Columbus, Ohto

1963-1964 - . - . Assistant Instructor, Department of Anatomy. The Ohio State University, Columbus, Ohio

1964-1965 - . - - Pre-doctoral Fellow, Institute of General Medical Sciences, Department of Anatomy, The Ohio State Univergity, Columbus, Ohio

1965 . . . . . Instructor, Department of Anatomy, The Ohto State University. Columbus, Ohto

PUBLICATIONS

"The Periperal Sympathetic Nervous System of Necturus Maculosa." J. Morph., 115: 109-120. Juzy 1964.

"Some Morphological Aspects of Neuroglia in the horse: A Silver Corbonate Study." Anat. Record, 151: 372. March 1965. (Abstract)

FTILDS OF STUIY

Major Fleld: Anatomy

Studies in Neuroanatomy. Professor James I. Hall

Studies in Gross Anatomy. Professors Linden F. Edwards and George R. I. Gaughran

Studies in Comparative Anatomy. Profeseor W. James Leach

Studies in Histology. Professor G. Adolph Ackerman

Studies in Enbryology. Professor John C. Weston 
CONTENTS

Page

ACKNOWLEDGMENTS ......................

VITA

111

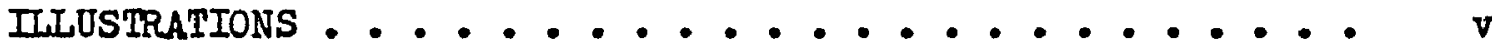

INTRODUCTION . . . . . . . . . . . . . . . . . 1

REVIEW OF THE IITERATURE . . . . . . . . . . . . . 3

A. Neuroglia: Comparative Morphology ........ 3

B. Neuroglia: Staining Characteristics and

Nomenclature ............ 8

MATERIALS AND METHODS

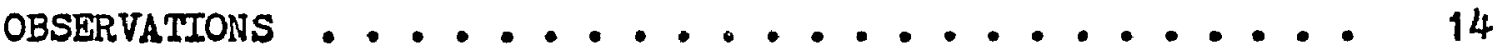

Fish: Dorosoma cepedianum ............ 15

Frog: Rana plpiens ............... 16

Lizard: Sceloporus undulatus ........... 17

Bird: Gallus domesticus . . . . . . . . . 18

Opossum: Didelphis virginianas . . . . . . . 20

Horse: Equus caballus . . . . . . . . . 23

Monkey: Macscus mulatta .............. 25

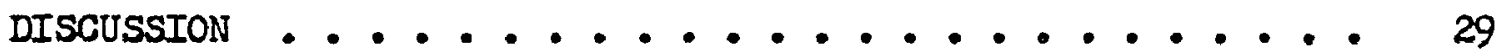

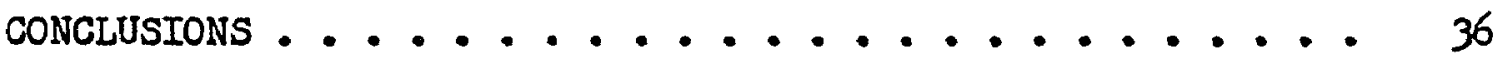

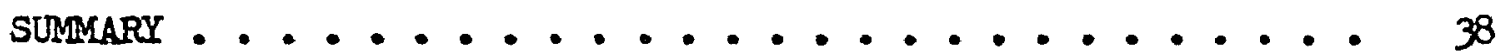

BIBLIOGRAPHY .......................... 40 


\section{IILUSTRATIONS}

Figure

1. Fish. Ependymal cells with elongate processes . . .

2. Fish. Union of ependymal processes into a larger bundle ......................

3. Fish. Sparcity of autonomous neuroglia . . . . . 45

4. Fish. Typical bipolar glial cell . . . . . . . . 45

5. Frog. Histology of presumptive hippocampal region. . 47

6. Frog. Tripolar glial cell with secondary branching of processes .............. 47

7. Frog. Vascular ending in presumptive basal ganglia. - 47

8. Frog. Blood vessel, neuroglia, neuron relationship. - 47

9. Frog. Neuron, neuroglia relationship . . . . . 47

10. Frog. Glial cell bodies related to blood vessel . . 47

11. Lizard. Neuron, neuroglia relationship . . . . . 49

12. Lizard. Variation in neuroglia processes . . . . . 49

13. Lizard. Presumptive hippocampus, marginal neuroglia ............... 49

14. Lizard. Neuron, neuroglia relationship ....... 49

15. Lizard. Vascular ending in basal ganglia . . . . 49

16. Lizard. Ependyma in presumptive hippocampus . . . . 49

17. Bird. Thick and thin processes related to a

18. Bird. Neuron, neuroglia relationships . . . . . 51

19. Bird. Glial variation in the basal ganglia ..... 51 
20. Bird. Neuroglia related to neuroglia ....... 51

21. Bird. Non-ependymal neuroglia in the hippocampus . 53

22. Bird. Ependymal cells in the hippocampus ...... 53

23. Bird. Neuron, neuroglia relations in basal. ganglia ........... . . . 53

24. Bird. Glial variation and glia to glia relations.. 53

25. Opossun. Oligodendrocytes . . . . . . . . 55

26. Opossum. Astrocyte with round cell body in the noocortex ........... 55

27. Opossum. Astrocyte with round cell body in the hippocampus ................

28. Opossum. Astrocyte with round cell body in the dentate gyrus ...............

29. Opossum. Stellate astrocyte . . . . . . . . 55

30. Opossum. Lamellar astrocyte .......... 55

31. Opossum. Astrocyte related to dendrites ..... 57

32. Opossum. Astrocyte relations to dendrites and astrocyte relations to other astrocytes - . 57

33. Opossum. Neuron, neuroglia relations . . . . . 57

34. Opossum. Neuron, neuroglia relations, and astrocyte related to astrocyte........ 57

35. Opossum. Astrocyte in the neocortex ....... 59

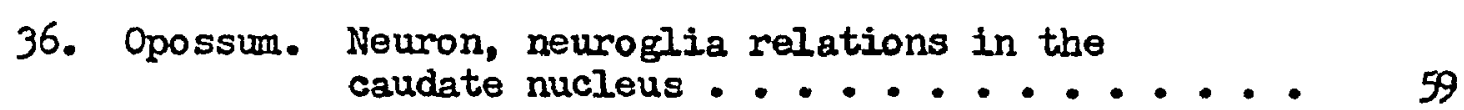

37. Opossum. Marginal layer of dentate gyrus . . . . 59

38. Opossum. Marginal layer of noocortex ........ 59

39. Horse. Variation in astrocyte vascular processes . . 61

40. Horse. Variation in astrocyte vascular processes . . 61 vi 
41. Horse. Astrocyte, oligodendrocyte, neuron relations in the caudate nucleus ...........

42. Horse. Astrocyte, oligodendrocyte relations in the precentral gyrus ..............

43. Horse. Neuron, neuroglia relations ......... 61

44. Horse. Neuron, astrocyte relations and astrocyte to astrocyte relations in the caudate nucleus . .

45. Horse. Neuron, astrocyte relations in the lentiform nucleus ................

46. Horse. Neuron, astrocyte, blood vessel relationship in the precentral gyrus .......... 63

47. Horse. Perivascular astrocytes .......... 63

48. Horse. Hippocampal-dentate gyrus area, neuroglia related to neuroglia.......... 65

49. Monkey. Astrocytes in marginal cortex ........ 67

50. Monkey. Precentral gyrus, middle cortical layers, neuron, astrocyte relations ........

51. Monkey. Astrocytes in deop cortical layers of

precentral gorus ..............

52. Monkey. Astrocytes with thick processes in deep cortical layers ....... . . . . . .

53. Monkey. Iinear astrocytes in precentral gyrus ... -

54. Monkey. Astrocyte, blood vessel, neuron relations, astrocyte, astrocyte relations in caudate nucleus ...............

55. Monkey. Astrocyte, astrocyte relations in caudate nucleus

56. Monkey. Clobus pallidus with nouron, neuroglia relations ...................

57. Monkey. Hippocampus-dentate gyrus region . . . . . 71

58. Monkey. Pyramidal cell layer of hippocarmus . . . . 
59. Monkey. Astrocyte variation in dentate gyrus . . . 71

60. Monkey. Glial processes in dentate gyrus . . . . . 71

61. Monkey. Vascular relations in precentral gyrus . . 73

62. Monkey. Vascular relations in supragranulor layers of precentral gyrus ......... 73

63. Monkey. Vascular process in dentate gyrus ..... 73

64. Monkey. Astrocytes with round cell bodies in the dentate gyrus ........... 73 


\section{INTPODUCTION}

Since the first description of neuroglia by Virchow in 1846 (21) a great deal of literature has been written pertaining to its morphology and proposed function. However, there are definite gaps in the anatomical ilterature pertaining to the neuroglia found in certain spectes and more speoifically, the neuroglia found in specific regions of the vertebrate central nervous system.

The purpose of this investigation is to determine the phylogenetic development of neuroglia in homologous cortical and subcortical forebrain regions of representative vertebrates. The glia are described (1) on the basis of the types of glia found in e2oh animal. (2) by comparing the types of glia found in selected regions in each animal. (3) on the basis of their relations to blood vessels, neurons and other neuroglia. The above histologlcal features of neuroglia are described in the hippocampus-dentate gyrus region, the basal ganglia, and the cerebral cortex (neocortex) or their presumptipe areas in the lower animals. These reglons were chosen because of thedr increasing functional importance as one ascends the phylogenetic scale, and because of their early phylogenetic differentiation and retention as distinct morphologtcal areas in higher animals. The antmals used represent various classes of vertebrates, Including Ostelchthyes, Amphibia. Reptilia, Aver, and Mamalia. Representatives of the above 
classes were chosen elther because of thedr generalized form or because of the absence of an adequate description of their neurogital morphology, or both.

The silver carbonate technique of del Rio Hortega $(29,30)$ with Scharenberg's modification (47) was employed because of its specificity for neuroglia and the detatied, precise histologlcal pleture that it reveals $(9,21)$. These histological results, however, must be interpreted in the Iight of recent advances with tissue culture techniques and the electron microscope. 
REVIEW OF THE LITERATURE

A. Neuroglia: Morphology

The literature pertaining to the exact species used in this study is sparse; therefore a portion of this section deals with work done on closely related animals. The Golgi method was used by Eurich (15) on Elasmobranch fishes and he reported that the cerebral hemispheres contained only ependymal cells with long processes terminating beneath the pia mater. Horstmann (27) described the neuroglia in the telencephalon of Elasmobranchs in sections stained with Cajal's gold sublimate and also found unipolar ependymal cells that he called "tanycytes." The latter author also described ependymal cells with end feet directly on blood vessels, as well as astrocytes located between the neurons, especially in one particular species. Eurich's paper deals largely with a description of glial elements in the spinal cord of various embryonic vertebrates. But he stated that the cerebrum of the frog (Rana temooraria) contains only ependymal cells with single branched processes. He also reported that the pigeon cerebral cortex has ependymal cells that still reach the periphery and astroblasts which are present in all cortical areas. Muller (36) made an important contribution to the comparative literature, but his descriptions were of the spinal cord of selected vertebrates. In the Teleost spinal cord he described ependymal septa 
which are bundles of ependymal processes that are passing from the ependyma to the perfphery of the cord. Comparative neuroglia studies on vertebrate spinal cords have also been done by Huber (32) and Pannese (38). Cajal (6) described the neuroglia found in the cerebrel heulspheres of the frog. He stated that there are ependymal cells present that send a process to the periphery of the hemisphere and terminate in a cone or cylinder. Achucarro (1) used silver tannin and gold sublimate in his work on the comparative structure of the rascular apparatus in the telencephalon of representative Teleosts, Amphibians, Reptiles and Aves. The flsh (Cxprinus auratus) forebrain showed ependymal glia with no vascular insertions, while the frog (Rana esculenta) exemplifled a similar morphology. except for thickenings of ependymal processes as they pass over blood vessels. Some processes stop on vessels and form an end foot resembling those found in mamals. In the reptile (Iacerta viridis) the telencephalon has ependymal cells with plal endings that often foin and form a triangular end foot. The only non-ependymal neuroglia in the forebrain are found in the presurptive basal ganglia region and septal maleus (1). The latter author pointed out that Cajal (6) disagreed with this last observation, as Cajal reported only ependymal elements in the telencephaton. Lchuoarro (1) also reported a great increase in the number of vascular end feet in the septal region, but this was not observed in other presumpttre areas of the telencephalon. The histological picture of the corpus striatum of the bird (Fringilia coelebs) was a protoplasulc and fibrous astrocyte framework with only 
2 fer primitive, elongated ependymal cell types (1). Vascular end feet are muerous and many astrocytes form cellular envelopes around the nourones. Cell bodies of astrocytes were 2 lso seen to form walls around large blood vessels. He concluded that the vascular attachment of neuroglia precedes autonomous glial elements phylogenetically and suggests the number of glial cells not retaining an ependymal attachment is related to the functional significance of a specific brain region. Penfield (41) stated that in the pinylogenetic development of neuroglia, the perivaseular foot is substituted for the periopendymal foot when blood vessels invade the brain. Heurons also cease to be associated with the ependymal foot processes when the glial cells become autonomous. More recent comparative morphological findings have been reported by Balrati and Maccaguani (4), Contu (8), Bairati and Maccaguani (3), Contu and Maccaguani (10), and Contu (9). These authors described the neuroglia of the telencephalon in 2 variety of vertebrates stained with the silver carbonate technique of del flo Hortega. The amphibian forebrain (Bufo vulgaria) and (Rana esculenta) demonstrated a sparse glial network made up almost entirely of ependymal fibers. Satellite cells were lacking around the neurones which was explained by two factors, the lack of neurones and the distance between the ependyra and the pia mater (4). (Lacerta muralis) and (viridis) were used as representative reptiles and the neuroglia forms were predominantly unipolar ependjmal cells or bipolar cells with a process directed toward the surface of the brain and the other process directed into the brain substance. No typical stallate forms 
of astrocytes were found, but there were some cells that had a fow short processes similar to the cell type found in the white matter of mammals. Perineuronal cells were rarely found in elther the presumptive hippocampal or basal ganglia reglons of the forebrain (8). The chicken (Gallus donesticus) was studied at varlous ages and it was found that all the types of glia structure were formed by the second month (3). The telencephalon had Bairati's (4) type III classification of glial architecture wich is made up of a delicate network of protoplasmic astrocytes, oligodendrocytes and perivascular fibrous astrocytes. These latter cells were related to each other by their processes (3). The neurons have a varlable number of satellite cells, but true perinouronal coverings are lacking. Numerous ependymal cell processes and protoplasenic astrocytes with short processes are present in the layers of the pallium (3). The corpus striatum and cerebral cortex of the horse (Equns caballus) were found to have predominantily protoplasmic astrocytes (10). The dominant cell type found in the hippocamus was the flbrous astrocyte wich was just the opposite from the rest of the pallium (10). The corpus striatum, cerebral cortex and hippocampus have a glial notwork of Bairati's type III in the ox (Bos tauras) which was comparable to the horse $(10,9)$. Transitional cells were also seen between protoplasmic astrocytes and flbrous astrocytes and between protoplasmic astrocytes and oligodendrocytes (9). Type III architecture was also present in the cerebral cortex and corpus striatum of the monkey (Macacus rhesus) (9). The predominant cell type found in the hippocampus, molecular and 
polymorphous layers of the dentate gyrus of the monkey was the flbrous astrocyte (9). Contu (9) further stated that the prinates have a glial morphology similar to man. He also pointed out that the cone nection betwen the density of glial structure and size of the nervous system does not exist in mamals. This latter observation has not been confirmed by Brizzee and Jacobs (5), Osorio (37), and Friede (18), who have done work on the gliameuron index in a number of vertebrates. These investigators stated that the glial density is related to both phylogenetic development and brain size. In addition, the glia-neuron Index was found to be related to the length of axones that arise from a particular mucleus $(19,37)$. Hawkins and 01szewskd (24) in their study of the gliamenuron index of the whale cortex reported a direct relation between glial density and brain size. The only paper that deals with the neuroglia of the opossun (Didelphis Firginianas) was a description of the distribution of oligodendrocytes (7). Camermeger (7) 21 so described the distribution of oligodendrocytes in the monkey (Macaca mulatta.) There vere a great number of peritrascular oligodendrocytes in the deep cortical lajers, globus pallidus and a diminished population in the pyramidal cell layer of the hippocampus, putamen and caudate nuclel (7). Inroughout the central nervous system of the dog and cat, oligodendrocytes were found to have astrocyte processes ending on them in a blunted or expanded tip (48).

The following is a sumary of the observations of Gloes (21), Hosokawa and Hajime (31) on the morphology and distribution of neurogita in various comon laboratory animals (cat, dog, rabbit, 
monkey) based on silver carbonate, gold sublimate, and colgl techniques. The superficial layers of the cerebral cortex were found to have small fibrous astrocytes with short processes (21). Nunerous perineuronal glial cells were found in the second and third layers of the cortex (21). The protoplasmic astrocyte was the most common cell type found in the cortical layers $(21,31)$. Flbrous astrocytes or transtitinal forms were found for the most part in the deop layers of the cortex $(21,31)$. Many perineuronal satellites and nouron related astrocytes were described in the basal ganglia $(21,31)$. The globus pallidus due to its ralation to white matter was found to contain large fibrous astrocytes (21). Flbrous astrocytes are the predominant cell type found related to neurons and blood ressels in the hippocampus (31). The distribution of nenroglia based on muclear stains was also discussed by Glees (21). Neuroglia distribution was not found to be essentially different in sections taken from different regions $(21,31)$.

B. Neuroglia: Staining Characteristics and Nomenclature The histology of neuroglia must be carefully interpreted due to the observations from tissue culture and time lapse photographic techniques. The dynamic activity of the fine protoplasmic membranes and their probable shrinkage upon flxation must be considered when observing sections of metallic impregnations $(44,45)$.

Del Riflortega's (28) review and generel clarification of the multiple terminology associated with nouroglia suggested that the 
following types of neuroglia exist: Protoplasaic astrocytes, fibrous astrocytes, ependymal cells, and four kinds of oligodendrocytes. Thts classification is based on cell size, number and thickness of processes. There are also intermediate types of astrocytes with characteristics of both kinds $(6,9,28)$. The term oligodendrocyte does not seem to apply to some of the cells identified as oligodendrocytes in the metallic impregnations by De Castro (13). However, in spite of thetr highly branched appearance, he falt the nome should be maintained. Tissue curture studies have revealed that the morphology of the oligodendrocyte is similar in the living and fixed state (13). These cells have also been described as clumping and joining processes in culture (35). Penfield (40) stated that "It is often difficult to say with certainty whether a cell is a large oligodendroglia or a small neuroglia". (astrocyte) (word in brackets is supplied by author). More recent investigations substantiate this latter statement $(9,3 i, 12)$. D'Agata (12) stated that neuroglial forms are so related structurally that it might be better to think of a single glial element. A recent attempt at classification was done by Bairati (2), who reported that the terms protoplasemic and fibrous astrocyto are unacceptable because of the enormous variation in cell size. Also, there is a group of oligodendrocytes which do not correspond structurally to "a cell with Pew processes." He proposed the following terms: fibrous gliocyte, based on the presence or absence of gliofibrils and other morphological features; oligodendrocyte, either found in white matter or as a perineuronal satellite; epitheloid 
gliocyte; trangitional gliocytes wich have intermediate characteristics between the first four cell types; and ependymal gliocytes. Balrati (2) concluded that the great polymorphism of the gltocytes is not the expression of special functions of the individual cell. The functions of the glia are found essentially in the differentiation that the cytoplasm undergoes and in the complexity of the architecture that the gliocytes form and not in the infinite gradation of their external form (2). Transitional forms similar to oligodendrocytes, the so called "mossy cells", were described by Ranon-Holiner (46) in the cat. Electron microscopic studies also have demonstrated mmerous variations and intermediate forms of neuroglia $(14,16)$. Duncan (14) found in the spinal cord of the rat "that intermediate forms are sufficiently mmerous to make classification of all cells encountered Into astrocytes, oligodendroglia, and microglia an over simplification of a morphologically complex array." 


\section{MATERTALS AND METHODS}

Soven different adult, vertebrate animals, representing flive different classes, and three different orders of Mamals wore chosen for this study. Representatives of Ostelchthyes, Amphibia, Reptilia. Aves, Mamalia, and the orders Marsupialia, Perissodactsla, and Primates wore selected. As a representative of flah, flve shad (Dorosoma cepedianum) (Lesueur). were obtained from the Ohio Department of Flsheries. The examples for Amphibia and Reptilita were seven Progs (Rana pipiens), and seven lizards (Sceloporus undulatus). which were secured from the General Biological Supply Co. For Aves, flve chiekens (Gallus domesticus), were obtained from The Ohio State University, Department of Poultry science. The above animals were sacrificed by decapitation and their calvaria renoved immediately. The whole brain was carefully removed and placed in Cajal's brom formalin (47) within ten minutes after death to insure adequate fixatton. As an example of Marsupialia, five opossums (Didelphis virginianas), were obtained from the Carolina Biological Supply Co. For Perissodactyla and Primates, seven horses (Equus daballus), and four monkeys (Macacus mulatta), were secured from the Ohto State University. Department of Veterinary Pathology. The opossums and monkeys were anesthetized with nebutal, decapitated, and then handled in the same manner as above. The horse brains were obtained at autopsy and fixed Immediately in Cajal's brom formalin. After an 
hour of flxation the larger brains (bird, opossum, horse, monkey) were sectioned transversely every three to four cm. to increase the diffuston of the fixative. The blocks of tissue were then sectioned on a Sartorius-Werke freezing microtome at fifteen micra, after three days of fixation. The entire forebratn of the flsh, the frog and the lizard was sectioned and random sections were selected and stained. Fifto to seventy-five sections were cut and stained from each of the selected areas of the bird, opossum, horse and monkey. The cerebral hemispheres of the three lower vertebrates (fish, frog, lizard) were cut in either cross or sagittal sections. These sections remained in Cajal's fixam tive for periods of time ranging from three weeks to eight months before staining with del Rio Hortega's silver carbonate technique (29, 30). Scharenberg's (47) modification of Hortoga's silver method was selected because of the uniform and reliable results obtained with the use of this method. The sections of the selected brain regions, namely, hippocampus-dentate gyrus region, other selected neocortical areas, and the basal ganglia were washed in distilled water, distilled water with twenty drops of amonium hydroxide for one to three mimites, distilled water for one! to two minutes, and then placed in a fifty cc. solution of "weak," "medium," or "strong" silver carbonate, plus twenty drops of pyridine, for forty-five minutes up to four hours, in a $45^{\circ} \mathrm{C}$ oven. Hyperbromation (heating at $45^{\circ} \mathrm{C}$ in the Iixation medium) before the staining procedure was started resulted in a better impregnation of some regions $(29,30)$. The "medium" or "strong" solution and longer time in the silver bath gave the best results in 
the fish, frog, and Iizard. The staining was then reinforced with 2 percent amnonical silver nitrate for twenty to thirty seconds, and reduced in 1 percent neutral formalin for one to two mimutes. It should be noted that this formalin is made up in fivo-hundred ce. quantities with the addition of twenty drops of pyridine. The next three steps were washing in distilled water, toning in a .2 percent solution of gold chloride for twenty to thirty minutes, and washing in distilled water. Finally the sections were fixed in a 5 percent solution of sodium thiosulphate, plus a few drops of ammontum hydroxide, washed in distilled water for five minutes, floated on slides, air dryed, dipped in xylol, and coverslipped with perseount. Acid cleaned glassware is absolutely necessery for consistent results. Also the glass rod used for transferring sections from dish to dish should be wiped with a plece of gauze between staining dishes to prevent precipitation.

This technique proved to be extremely accurate in demonstrating the processes of neuroglial cells and their relationships to blood vessels, neurons, and to other glia.

The microphotographs were taken on a Zeiss photomicroscope using Adox KBI 4 black and white film. 


\section{OBSERVATIONS}

The presence or absence of the following macroscopic brain regions (or their primordium). (1) hippocaupus, dentate gyrus, (2) precentral gyrus, (3) globus pallidus, (4) putamen, caudato nucled; and the use of their phylogenetic nomenclature. (1) archipalifum, (2) neopallium, (3) paleostriatum, (4) neostriatum, was based on the work of Crosby, Humprey, and Lauer (11), Herrick (25), Hoffman (26), Johnson (33), Kappers, Huber, and Crosby (34), and Papez (39). The archipallium or its presumptive area was present in all the aniaals used in this study. The paleostriatum was considered to be present from fish to man (11). However, functionaliy the fish forobratn was considered largely an olfactory organ by many authors $(33,34,39)$. Therefore the striatum will not be described as a distinct anatomical region until the Amphibia. Since the representation of the neopallium was so swall in the lizard and its speciflc location not clear in Aves (34), it was not considered as a morphological region until Marsupialia. Analogues of the neostriatum are indicated in Reptilia and Aves, but a distinct caudato nucleus was not observed until Marsuplalia. The putamen was not prominent until the primates. The terms protoplasmic and flbrous astrocytes were not used because of the inability to distingaish gliofibrils in our allver carbonate preparations. The latter cell types could be distinguished 
on the basis of cellular shape, and muber and thickness of processes, but it was evident that the variations of these classical cell topes make this terminology an oversimplification. Astrocytes were described on the basis of the shape of their cell bodies and the number and thickness of processes and simply referred to as astrocytes. The more primitive polar, non-ependymel glial elements (unipolar, bipolar, tripolar) observed in the lower vertebrates were not clearly astrocytes or ollgodendrocytes. Therefore, they were generally considered as primitive adaptations of glia cells that had migrated from the ependsma. Absence of perivascular feet, smaller cell bodies, and more delicate expansions were considered as criteris for the identifieation of olfirodendrocytes $(31,42)$. Thts too was recognized as inadequate terminology because of transitional forms; however, the above morphological characteristics were chosen for our descriptions. These criteria were considered the most accurate in the light of past nomenclature and recent investigations with tissue culture and the electron microscope.

\section{Fish: Dorosoma cepedianum}

The neuroglia of this species were for the most part ependymal cells, with their cell bodies lining the first and second ventricies (FIg. 1). Flongate processes were seen to pass into the forebrain which often joined (three to five) to form larger bundles of processes (Fig. 1). These processes (single or bundles) were observed to cross or course in close relationship to both neurones and blood 
ressels (FIgs. 1, 2). The lattor processes could be traced for a constderable distance and terminated just beneath the pia mater in a slight enlargement. The bundles separated, just bofore their termination, into individual processes. Non-ependymal bipolar and tripolar glial cells were 27 so found and when present were associated with the large multipolar neurons as opposed to the small granule nerve cells (FIg. 4). Flgure three demonstrates a typical bipolar glial cell with its cell body closely related to a blood vessel and one of its processes coursing over a neurone. This later relationship was rare as the non-ependymal bipolar elements were not usually seen in physical contact with blood ressels or neurons. However, ocm casional small, round glial elements with no visible processes were observed in a satellite position to the large neurons. No typical end feet as seen in higher animals were found associated with the blood vessels.

Frog: Rana ptpiens

The presumptive hippocampus and striatum of this ammal had a predominance of ependymal glial elements (Fig. 5). These cells had single long processes that coursed from their cell bodies to subpial terminations. Fnd feet were observed fust beneath the pia mater. The ependymal processes were closely associated with neurons as they passed through the forebrain (FIg. 5). The bundle formation of opendymal processes was not observed in either primitive brain region. However, a glial network was apparent due to the secondary branching 
of glial processes (FIgs. 5, 6). Non-ependymal glia were present and had round to oval cell bodies wth from one to three processes that exemplified various degrees of secondary branching (Flgs. 6, 8, 9). When observed in cross section the striatum had more free glial elements in the marginal layer (between the neurons and the pia) in comparison with the hippocampus (Fig. 5). The nonmependymal polar cells were observed with one or more of their processes orlented to the pia or a neuron (FIg. 9). However, the muber of neuroglia th a process related to a neuron or a glia cell in a satellite position was sparse. The vascular relationships found in this animal were more complex than in the fish. Some cells were found with their cell body directiy on a blood vessel and a single process with varying degrees of secondary branching directed away from the vessel (FIg. 8, 10). Cells with a single process wrapped around a blood vessel were also observed (Fig. 7). Occasional vascular end feet from ependymal cells were found, and ependymal processes were also observed to course along the vessel walls. Enlargements or areas of increased thickness were found where the processes were related to a blood vessel.

\section{Lizard: Sceloporus undulatus}

Ependymal cells with single, elongated processes were the most common glial cell type found in the presumptive hippocampus and striatum (Fig. 16). In the hippocampus, ependymal processes occasionally bifurcated before their termination and were observed to end in a subpial end foot or in relation to a neuron (Figs. 14, 16). 
Vascular end feet or skein type netiorks were also seen as endings of ependymal cell processes. The processes of the ependymal cells in the primitive noostriatum could not be traced for any great distance. However, in the more ventral paleostriatum subplal terminations were observed. A variety of non-ependymal neuroglia were found ranging from small bipolar elements to large oval or polygonal multipolar cells (Figs. 11, 13, 14, 15). A variation in the thickness and in the secondary branching of processes was observed in some of the larger cells (FIg. 12). The non-ependymal neuroglia were observed with their processes oriented toward neurons and the pia meter in both regtons examined (Figs. 11, 13, 14). A few rere glial cells without impregnated processes were found in a satellite position. The vascular relations of the non-ependymal neurogila were (1) a process with a vasoular end foot (Fig. 15), (2) a process without an enlargement related to a vessel, and (3) a cell body lying on a blood ressel uith a process directed away from the ressel. The latter vascular related cells were unipolar in most instances. In the paleostriatum an occastonal polygonal shoped neuroglia with thick branching processes was found (Fig. 12). On the basis of their morphology these cells could be considered astrocytes. Marginal neuroglia (between the neurons and the pia mater) were observed in both the presumptive striatum and hippocampus (FIg. 13).

Chicken: Gallus domesticus

Unipolar ependymal cells and a number of non-ependymal bipolar and tripolar neurogila with round cell bodies were observed in the 
primtitive hippocampus (Figs, 21, 22). The ependymal cells appeared to be more numerous, but as one passes from ventro-medial to dorsolateral on the dorsel aspect in a transverse section of this region the free elements increased in mumber (Figs. 21, 22). A complex network of glial processes of ependymal cell origin was observed around the neurons (FIg. 22). Most of their terminations were subpial, bat as the ependymal processes passed to the pia they were closely associated with blood vessels as well as neurons. The nonependymal cells were often found in the marginal region and closely associated with neurons (Figs, 21, 22).

Ependymal cells with short processes that could not be traced for any great distance were found along the ventricular border of the paleostriatum. However, there was a greater number of astrocytes and oligodendrocytes present in the striatum as compared to ependymal cells (FIgs. 19, 20, 24). - The following variety of forms were observed: (1) a typical oligodendrocyte ( small, round cell body with two to four processes); (2) transitional forms (cells with morphological characteristics between typical oligodendrocytes and stellate astrocytes); (3) astrocytes (cells with larger, round to slightly polymorphic cell bodies, four to eight processes, and a variation in the degree of secondary branching and thickness of their processes); (4) typical stellate astrocytes (Figs. 19, 20, 24). The cell described above (number 3) was considered to be an astrocyto because of the thickness and number of processes it possessed and because of its relative size as compared to typical oligodendrocytes. There 
was also a number of neuroglia that were transitional between the astrocyte with a round cell body and the typical stellate form. The akove transitional cells were observed to have a slightly polygonal cell body, and an increase in the thickness and length of their processes (FIg. 23). Astrocytes with round cell bodies and transitional forms toward the typical stellate astrocyte were often found with their processes encompassing neurons and terminating adjacent to the pla mater (Figs. 18, 23). Astrocytes were also present lying directly on the pertkaryon of a nerve cell (Fig. 23). Processes of one astrocyte were observed to be in intimate association with the cell body of other astrocytes (FIgs, 20, 24). Vascular end feet were found on blood vessels from both the round and stellate forms of astrocytes (Figs. 17, 18). A consistent varlation found in the apearance of rascular processes was their thicknoss (FIg. 17). Some wore extremely large, with thick extensions terminating as an end foot, while other terminations were very fine and delicate (Flg. 17). The larger stellate astrocytes were observed related to blood vessels and were also found in the white matter near the neurons of the striatum (Flgs. 17, 19, 24). Interfasicular oligodendrocytes were more numerous as opposed to perisomatic oligodendrocytes (Figs. 19, 20, 23. 24).

Opossum: Didelphis virglnianas

The ependymal cells of this animal did not have processes that project from the ventricular surface into the brain. A transitional 
series of neuroglia was observed from the small round oligodendrocyte to the large stellate astrocyte (Figs, 25, 26, 27, 28, 29, 30). Astrocyte cell bodies varied in appearance from round, to oval, to slightly polygonal, to stallate. The number of processes varied from four to twelve. Astrocytes were observed with fine delicate processes (Fig. 38), heavy thick processes (Figs. 29, 30), and with a combination of thick and thin processes (FIgs. 27, 28). The thick processes were often related to blood vessels (Flg. 26), nerve cell processes (Flg. 32), the cell bodies of newrons (FIg. 34), and neuroglia (Fig. 34).

In the three layers of the hippocampus the dominant cell type present was an astrocyte with a round to slightly polygonal cell body (FIgs. 31, 32). A few typical satellite oligodendrocytes and astrocytes were found in the pyramidal cell lajer (FIgs. 31, 32). The latter astrocytic processes were usually associated with the perikaryon of a nerve cell (FIg. 33). Astrocytes were also found related to each other via a close approximation of their cell bodies (FIg. 32). A large number of astrocytes were found with thick processes directly related to the apical dendrites as they radiate from the pyramidal cells (FIgs. 31, 32). Ihis latter observation was more characteristic of the pyramidal cell dendrites as one passes from the point of in volution of the hippocampus to the region where the pyramidal cell layer blends with the polymorphic layer of the dentate gyrus. Numerous astrocytes with round to slightiy polygonal bodies were present in the molecular and polymorphic layers of the dentate gyrus 
(Figs. 34, 37). Gilal cells were not visualized in the gramular cell layer (FIg. 37). However, astrocyto processes were observed alosely related to the cell bodies of the latter nourons. The astrocyte cell bodies were located in the polymorphic and molecular lajers. Astrocytes of the polymorphic lajer were related via thedr processes to both neurons and other astrocytes (FIg. 34).

The marginal region of the neopallium was sparsely populated with round to polygonal shaped astrocytes as compared with a similar region in the dentate gyrus (FIgs. 37. 38). The processes of the above cells were thin and demonstrated little secondary branching (Fig. 38). Relationshtps were observed between astrocyte processes and blood ressels (Fig. 26), betreen astrocyte processes and cell bodies of adjacent astrocytes (FIg. 38), and between astrocyte processes and the pia mater (FIg. 38). The cortical layers of neurons appeared to be sparsely populated with neuroglia in comparison to the archipallium (FIg. 35). Satellite oligodendrocytes and oval to polygonal shaped astrocytes were the cell types found in the neocortex. Astrocyte processes generally numbered from two to four with an occastonal highly branched cell present (FIg. 35). The above processes were fine and delicate and were often related to neurons (FIg. 35). Astrocytic elements similar to the cell types found in the cortical layers of the neepallium were seen in both the caudate and lentiform maclei (FIg. 36). Glial forms were sparse in both these areas of subcortical grey matter, except for a netrork of glial fibers seen along the ventricular surface of the caudate nucleus. 
The thin processes of the astrocytes were often seen contacting neurons (FHg. 36).

\section{Horse: Equus caballus}

A transitional series of glial cells similar to that found in the chicken and opossum was observed in the horse. Larger cells (FIg. 40), more polygonal cell bodies (Fig. 46), and more, and thicker processes (Figs. 39, 40,44, 48) were the principle varlations in cellular worphology found in this animal as compared with the opossum. The pyramidal and molecular layers of the hippocampus showed the following cell types: (1) small, round to slightly polygonal astrocytes (Fig. 43); (2) typical stellate astrocytes; and (3) oligodendrocytes. Small astrocytes with round to polygonal cell bodies were closely related to the large pyranidal neurons (FIg. 43). As contrasted with the opossum, astrocytes were more evenly distributed between the cell body and the apical dendrites of the pyramidal neurons. A varlety in the number (four to ten) and thicknesses of the astrocyte processes was observed (Fig. 43). The thicker processes were often seen contacting a neuron or a blood vessel. There appeared to be a general insrease in the number of astrocytes in all hippocampal layers as compared with the opossum. The number of satellite ollgodendrocytes around the pyramidal cells also appeared to increase in number as compared to the opossum. A dense network of gltal processes was observed in both the gramular cell and polymorphic layers of the dentate gyrus (FIg. 48). The processes were found closely related to 
the granular neurons and had their cell bodtes in either the polymorphic layer of molecular lajers. The neurons of the polymorphte layer were in intimate contact with both satellite oligodendrocytes and the processes of round to polygonal shaped astrocytes. The processes of the latter cells were observed to have varyling degrees of thicknesses. Thick processes were often seen contacting blood ressels, neurons or the processes and cell bodies of other neuroglia (Fy. 48). In the network of glial processes seen in the polymorphic layer; processes of astrocytes appeared to be closely associated with the processes and cell bodies of other astrocytes (Fig. 48). Also oligodendrocyte processes were closely related and at their point of contact with the processes of other oligodendrocytes there appeared to be an increase in the thickness of the processes (FIg. 48). This latter observation was also seen between the processes of small polygonal shaped astrocytes and typical round oligodendrocytes. There were abundant round to polygonal shaped astrocytes with their processes related to the pia mater and to blood vessels in the molecular layer of the dentate gyrus. In the marginal area of the precentral gyrus were found both large stellate astrocytes and small round to polygonal astrocytes (FIgs. 40, 47). Processes generally numbered from four to twelve and were often elongate with some degree of secondary branching (Figs. 40, 47). Hlongate thin processes were related to blood ressels (Fig. 40), and the cell bodies of astrocytes were also seen lying directly on vessel walls (Fig. 47). Thick processes were demonstrated with typical vascular end feet in other 
corticel Iayers and in the basal ganglia (71g. 39). In the deep layers of the cortex stellate astrocytes, round to polygonal astrocytes, and satellite ollgodendrocytes were found related to neurons (Fig. 46). The thin processes of the astrocytes were oriented toward blood vessels and were seen in contact with the processes and cell bodtes of neurons (FIg. 46). Also in the neopallium the processes of astrocytes appeared to end on the cell bodies of oligodendrocytes (Fig. 42).

In the caudate nucleus were found large stellate astrocytes with their thick processes related to blood vessels, neurons, and other astrocytes (Fig. 44). Satellite oligodendrocytes were also observed around the neuron celI bodies (Figs. 44, 45). Astrocytes with oval cell bodies were observed to send their thin processes to neurons (Fig. 41). The cell body or a process of the latter astrocytes was also found closely related to oligodendrocyte cell bodies (FIg. 41). Astrocytes were also present in the paleostriatum, but they were generally the small round to polygonal astrocytes (F1g. 45). The latter cell processes appeared to be in physical contact with neurons as did man satellite oligodendrocytes (Fig. 45). There appeared to be a definite increase in the number of neuroglia in the horse caudate and lentiform nuclel as compared with the opossum striatum.

\section{Morkey: Macacus mulatta}

The trangitional forms and general cell types of neuroglia described in the opossum and horse were also observed in the monkey. In comparison to the horse and opossum the following general 
differences in cellular morphology were observed: (1) an increase in the number, length, thickness and branching of processes (Flgs. 55, $60,64) ;(2)$ a more apparent number of vascular relations (Figs. 52, 61); (3) the cell bodies were more plemorphic (Figs. 49, 53, 64). Astrocytes with round to polygonal cell bodies were the dominant cell type found in the pyramidal and polymorphic layers of the hippocampus (FIg. 58). These latter cells were often associated with the apical dendrites of the pyramidal cells (F1g. 58), as opposed to the perikaryon. Satellite oligodendrocytes were also associated with the above cell bodies (Flg. 58). Stellate astrocytes were commonly found in the molecular loyer of the hippocampus. A dense glial network was found in the polymorphic layer of the dentate (Fig. 60). Typical astrocytes with round cell bodies, as observed in the opossum and horse, were evident (Figs. 59, 60). However, there was an apparent increase in the number of processes per cell and man more polygonal to stellate shaped astrocytes (Figs. 59, 60). The neurons were in intimate contact with the glial processes (FIgs. 59, 60). Astrocyte processes were found related to other astrocyte and oligodendrocyte cell bodies (Fig. 59). Relationships between processes of the above glial elements ware also noted (Figs. 99,60 ). Manj of the processes were obviously related by chance. However, others were observed with an apparent increase in thickness at the point where the processes were closely related, as previously noted in the horse. Clial cell bodies were not impregnated in the granular cell layer, but a network of processes from astrocytes in the polymorphic and molecular layers 
was observed. Relationships between astrocytes and the pia mater, as well as blood vessels were present in the molecular layer of the dentate gyrus as noted prevsously in the opossum and the horse.

The precentral gyrus presented a transition of cellular morphology as one passes from the marginal cortex to the deep cortex and white matter. The marginal area demonstrated a variety of cells from stellate astrocytes to oligodendrocytes (FIg. 49). However, the most common cell type present was the round to slightly polygonal shaped astrocyte (Fig. 49). These latter cells were often related to the pia mater or to blood vessels (Fig. 49). A great deal of pleomorphisn with many astrocytes related to the perikaryon and processes of the neurons was found in the middle cortical layers (Fig. 50). Satellite oligodendrocytes were apparent in all cortical layers (Fig. 50). The deop cortex was characterized by a general increase in the thickness of the processes of astrocytes (Fig. 52). However, round to oval to stellate astrocytic forms were still observed (FIg. 51). The thicker processes were oriented toward blood ressels and were in contact with neurons (FIgs. 51, 52). Typical stellate astrocytes were found in a Iinear orientation in the white matter adjacent to lajer six of the cortex (Fig. 53).

The neostriatum had the following cell types: (1) round to slightly polygonal shaped astrocytes (Figs. 54,55); (2) oval shaped astrocytes with thin processes (FIg. 54); (3) large stellate astrocytes with thick elongated processes (Fig. 55); (4) oligodendrocytes (FIg. 54). The larger astrocytes were observed with their processes 
related to neurons, blood vessels, and to the processes and cell bodies of other astrocytes (FIgs. 54, 55). In the caudate mucleus astrocytes were often larger than the neurons they were related to (FIg. 55). In the paleostriatum were found topical small astrocytes with round to otal cell bodies (Fig. 56). The latter cells as well as satellito ollgodendrocytes were found related to the larger motor neurons of the globus pallidus (FIg. 56). The processes of the astrocytes were in intimate contact with the neuron cell body and often formed a network around the cell (Fig. 56).

An increase in gliamvascular relationships was apparent in all three regions used in this study. A single process usually thicker than the other processes of the cell was found to end on the vessel walls (Figs. 61, 63, 64). Other processes were observed to terminate by wrapping around the vessel walls (FIG. 52). However, thin delicate processes were also directed toward blood vessels (FIg. 62). 


\section{DISCUSSION}

This study was undertaken to determine whether a relationshtp to neuronal complexity and specialization of localized regions of the vertebrate telencephalon would be reflected by neuroglia morphology. In addition, a study of the phylogenetic devalopment of neuroglia morpbology might further establish the importance of neurogila in known areas of complex neuronal activity. Previous authors (15,6,1,4,8) have reported that ependymal cells were the dominant or only glial element found in the forebrain of the fish, frog and lizard. However, a few primitive, non-ependymal glial cells were found in all the above antmals that were used in this study. The autonomous (non-ependymal) neuroglia of the flsh (Dorosome epedianum). the frog (Rene pipiens). and the 11zard (Sceloporus undulatus) generally had round cell bodies with from one to four processes. These cells were found with their processes related to neurons, blood ressels, and the pla mater. The terdency of glial cells to 1080 their primitive ependymal position and to make secondary connections with blood vessels and neurons was increasingly evident from the flsh to the Iizard. Vascular attachments in the flsh were rare, but a deflnite increase in the frog and lizard was observed. A true vascular end foot was first, observod in the Iizard. No major differences in glial morphology of the frog were found in the primitive hippocampus and striatur. A fer polygonal, 
multipolar neuroglia with branched processes were found in the ventral striatum of the lizard. The torm astrocyte was not justified in the three lower vertebrates except for this latter cell. An apparent phylogenetic trend was observed in the following neuroglia-vascular relations: (1) ependymal cell processes were observed passing over vessels (fish); (2) enlargements of ependymal processes were related to vessels (frog); (3) ependymal processes terminated on vessels (frog. lizard); (4) non-ependymal coll bodies were lying directly on blood vessels (frog, 11zard); (5) non-ependymal cell processes were urapped around blood vessels (frog); (6) vascular end feet from non-ependymal cells terminated on vessels (Iizard). The above observations were in general agreement with Achucarro (1). The vascular end foot was still apparent as the type of vascular attachment in the chicken, opossum, horse, and monkey. The cell bodies of 28 trocytes were observed to be directly related to vessel walls from the frog to the horse. A variation in thickness of the vascular processes was noted from the chicken through the monkey. This variation has been found as a morphological difference by other authors $(6,21,31)$. However, it should be mphasized as a consistent difference and possible indicator of the functional state of an astrocyte. Enzymatic and lonic differences in astrocytes have strongly implicated this cell in a water-ion transport mechanism betreen the vascular system and the neuron $(17,20)$. The morphologic evidence seens to support this theory. From a phylogenetic standpoint the number and thickness of vascular processes increased from fish to monkey. This too supports the above theory, as a higher 
degree of neuronal metabolism would require a more efficient transportation system between blood ressel and nouron.

Balrati (2) diacussed the functions of glia in terms of cytoplasmic differentiation and concluded that the polymorphism of neuroglia was not an expression of function. Our findings do not substantiate this statement. The anatony of neuroglia was reflectod in the alie and shape of their cell bodies, and the muber and thickness of their processes. As one ascends the phylogenetic scale from fish to monkey the archipallium, neopallium, and striatum showed a parallel degree of complexity of the above morphological features. The relationship of these cells to neurons, to blood vessels, and to other neuroglia also increased in a similar pattern. The specific functions of neuroglia may be reflected in enzymatic complexity and cytoplasmic differentiation. However, the adaptions of primitive round cells with few processes into larger, polygonal, multipolar cells with many processes suggest a degree of functional difference. This is further confirmed by the intimate relationships found between glial processes, neurons, blood vessels, and other neuroglia. The round to slightily polygonal shaped astrocyte was found from the chicken to the monkey, but this cell was also observed to increase in polarity and in number and thickness of processes from the chieken to the monkey. The cell body described as round may well demonstrate a greater angularity in Vivo. This was not apparent, however, because of the possible shrinkage of the fine plasma membranes during flxation as suggested by Pomerat $(44,45)$. The dynamics of neuroglia must also be considered 
when observing static histological sections. Missue culture studies (44. 45) have indicated that the surface membranes of glial processes are extremely active. They are constantly being extended and retractod, which suggests the functional state of a particular cell. This further indicates that the mmber of processes a cell displays Indicates the functional activity of that particular cell. The morphological changes observed in the untpolar ependymal cell found in the fish, frog. Iizard, and chicken also indicate the importance of the adeptation of processes. The following sequence was observed: (1) ependymal subpial terminations ( $f i s h$ ); (2) ependymal enlargenents as they coursed over blood ressels (frog); (3) ependymal terminations on blood vessels and neurons (11zard). These modiflcations could be explained by the progressive increase in the thickness of the wall of the forebrain and/or the Increased metabolic demands of the neurons. The epproximation of glial cell bodies and/or their processes to neurons was found in all the animals used in this study. Fpendymal cell processes were observed in close relationship with neurons in the fish, frog. Ilzard and the presumptive hippocampus of the chicken. Their processes formed a network around neurons that was evident in the frog, lizard and bird. An increasing number of non-ependymal glia related to nourons was found from the fish through the chicken (Just hippocampal area). The lattor glial processes were thin and appeared to contact nerve cell bodies. A progressive increase in satellite oligodendrocytes and astrocytos with their processes related to neurons was found in the striatum of the chicken and all the forebrain 
regions of the opossum, horse, and monkey. Thin processes were still present in the higher phylogenetic specles, but thicker processes were more evident. The greater increase in membrane contacts between glia and neurons presented by thicker processes and satellite oligodendrocytes suggests morphologic evidence of the reported biochemical relations of neurons and neuroglia. Inverse enzymatic changes were reported in nourons and glia following stimulation (23), and some steps in the tricarboxglic cycle appear to be performed more efficlently in glia and others in nerve cells (22). The morphological evidence appears to augment biochemical evidence as one ascends the phylogenetic scale. The more complex the nervous system, the greater the metabolic requirements, and concurrently the greater the mumber of neuron-glia relations that are observed. The above general trend has been suggested by nuclear counts in glia-index studies $(5,18,24)$. These latter studies indicate the number of glia as compared with the number of neurons. This technique yields valuable information; howover, metallic impregnations reveal a more complete picture in that processes are stained. Astrocytes were found related to the dendrites of the large pyramidal cells of the hippocampus in the opossum, horse, and monkey. This rould place them in a more advantageous position to recelve bountons, as has been reported by Scheibel and Schedbel (48). This also places them near the part of the neuron that is receiving a constant bombardment of impulses and those motabolic denands would be in a constant state of flux. 
Close relationships were also found between glial cells and other neuroglia in the chicken (striatum), opossum, horse, and monkey. Astrocyto processes were observed in relation to both astrocyte and oligodendrocyte cell bodies. The cell bodies of astrocytes were approximated to other astrocyte cell bodies. Adjacent astrocyte processes were found in close association in the dense glial network in the polymorphic layer of the dentate gyrus. At the point of approximation there appeared to be an increase in the thickness of opposing processes. Oligodendrocyte processes were also observed in similar relationships in the polymorphic layer of the dentate grrus. The observation that neuroglia are closely related to other glia via their processes is substantiated by Pomerat's movies of oligodendrocyte cultures. Thtckened areas were observed between crossing processes, and processes were observed in physical contact with cell bodies. These relationships were not static, but were apparent as these cells moved in the culture medium. The process-to-process relationship was only observed in the horse and monkey, but the process to cell body association was found in the bird (striatum), opossum, horse, and monkey. The electron microscope has demonstrated a five-layered membrane unit between adjacent oligodendrocyte cell bodies and a similar relationship between astrocyte cell bodies (43). Contacts between cell bodies and processes, and processes with adjacent processes were also reported (43). The blunt tips of astrocyte processes were found to end on ollgodendrocytes in the metallic Impregnations of Scheibel and Scheibel (48). The assumptions that 
astrocytes are the nutritional link between blood vessels and nourons of the central nervous system and that oligodendrocytes have the metabolic machinery to supply nutritive or high energy compounds to the nerve cell are generally accepted. Perhaps the increased thickness between processes of astrocytes and oligodendrocytes or the termination of astrocytic processes on oligodendrocyte cell bodies could be another type of link between the vascular system and the neuron. The astrocyte is usually pictured as directly interposed between the vessel and neuron. The close association of glia cells of the same type suggests a possible nutritional or electrical communication of the neuroglia netrork of cells and processes. The observations that relationships between neuroglia, blood vessels and neurons are more complex as one ascends the phylogenetic scale further establishes the functional importance of the glia cell. Also the intimate contacts between the glta cell bodies and processes is suggestive of a degree of complexity not proviously mentioned in the Iiterature. 


\section{CONCLUSTONS}

1. Ependymal cells with elongate processes are the dominant type of neuroglia found in the forebrain of the flsh, and in the presumptive hippocanpus and striatum of the frog and lizard.

2. Non-ependymal glial cells are present in increasing numbers in similar areas of the forebratn from the flsh through the lizard.

3. The bird telencephalon represents a transitional phylogenetic stage from a dominance of ependymal glia to a dominance of non-ependymal glia.

4. The appearance of astrocytes and vascular end feet, similar to those described in mamnals, was first noted in the paloostriatum and archtpallium of the lizard.

5. Variations in the thicknesses of vascular processes were apparent from the bird to the primate.

6. Astrocytes present a polymorphic transition of cells from small, round to slightly polygonal shaped cell bodies to large stellate forms. These cell types were evident in the chicken, opossum, horse, and monkey.

7. The number, thickness, and degree of secondary branching of astrocyte processes increased from the bird to the primate.

8. An increase in neuron-neuroglia relations in the hippocampusdentate gyrus, the striatum and the neocortex or their respective 
precursors, was found as one ascends the phylogenetic scale from fish to primate.

9. In selected forebrain areas thick glial processes associated with neurons were more apparent from the bird to the primate.

10. In selected forebrain areas the degree of cellular polarity observed in astrocytes increased from the bird through the primate.

11. Astrocyte processes are found related to the cell bodies of other astrocytes and oligodendrocytes in the striatum of the chicken and in the archipallium, neopallium and striatum of the opossum, horse, and monkey.

12. The processes of astrocytes were found in close approxdmation to each other as were oligodendrocytes. The polymorphtc lajer of the dentate grous of the horse and monkey best exemplifled these relationships. 


\section{SUMMARY}

This study was undertaken to determine the phylogenetic development of nouroglia in specific areas of the vertebrate forebrain. The hippocompus-dentate grrus region, striatum, and neocortex or homologous, presumptive areas from the following vertebrates wore stained with Scharenberg's modification of del Rio Hortega's silver carbonate technique: Flsh (Dorosoma cepediamm), Frog (Rana plplens), Lizard (Sceloporus undulatus). Bird (Gallus domesticus), Opossum (Didalphis Virginianas), Horse (Equus caballus), and Monkey (Macacus mullata). Ependymal cells were the dominant glia cells present in the flsh, frog, and lizard. Non-ependymal cells were found in increasing numbers from the flsh to the lizard. The bird represents a transitional stage between a dominance of ependymal cells and a dominance of non-ependymal cells. Astrocyte variations in morphology are described in the chicken, opossum, horse and monkey. The number, thickness and degree of branching of astrocyte processes are interpreted as morphological adaptations of a basic cell type that suggest a functional importance. The variations in thicknesses of vascular processes is suggested as a functional indicator for astrocytes. Neuron-neuroglia relationships were found to increase as one escends the phylogenetic scale. The importance of this is discussed. Neuroglia were also found in close 
association to other glia in the bird, opossum, horse, and monkey. The number of neuroglia found in relation to blood vessels, neurons and other glia parallels the degree of phylogenetic advancement. 


\section{BIBLIOGRAPHY}

1. Achucarro, N. De I'Brolution de la Neuroglie et Specialment de ses Ralation avec I'Appareil Vasculaire. Trab. Lab. Invest. Biol.. 13: 169-212. 1915.

2. Bairati, A. Norfologia e Struttura dei Gliociti. Biol. Latina, 2: $601-659$. 1949-50.

3. and Maccaguani, F. Richerche sulla Glioarchitettonica dei Vertebrati. II Ucelli. Monitore Zool. Italiano, 58

Suppl.: 53-55. 1950.

4. and Maccaguani, F. Richerche sulla Glioarchitettonica del Vertebrati. I Anifibi. Monitore Z00l. Italiano, 58 Suppl.: 49-52. 1950 .

5. Brizzee, K., and Jacobs, I. The Glia/Neuron Index in the Submolecular Layers of the Motor Cortex in the Cat. Anat. Rocord. 134: 97-105. 1959 .

6. Cajal, R. Histologie du Systeme Nerveux de L'Home et des Vertebres. Vol. 2. Maloine, Paris. 68-71,79,106,504-518,731-761, 824-846. 19T1.

7. Cammermeyer, J. The Distribution of Oligodendrocytes in CerebraI Gray and White Matter of Several Mammals. Am. J. Anat., 107: 107-127. 1960 .

8. Contu, P. Richerche sulla Gioarchitettonica dei Reitili (Cheloni, Sauri $\theta$ Ofidt). Arch. Ital. Anat. $\theta$ Embriol.. 58: 295-320. 1953.

9. Richerche sulla Glioarchitottonica del Vertebrati: Mamiferi (Cetacei, Edentati, Roditori, Insettivor, Chirotteri, Carnivori, Perissodatilli, Artiofatilli, Primati). Arch. Ital. Anat. $\theta$ Embriol., 29: 101-141. 1954.

10. and Maccaguani, F. Richerche sulla Giloarchitettonica del Vertebrati. V Ungulati. Monitore Zool. Itallano, 58 Suppl.: 98-100. 1950.

11. Crosby, E., Humphrey, T.. and Lauer, E. Correlative Anatomy of the Nervous System. Macmillan, New York. 379,380,411,423,424. 1962. 
12. D'Agata, M. Richerche sulla Morfolgla e Classiflcazione dell' Oligodendroglia. Riv. Neurol.. 20: 81-127. 1950.

13. De Castro, F. Sobre el Compartamiento y Signification de la Oligodendroglia en Ia Substancia Gris Central y de las Gliocitos en las Ganglias Nerviosos Perifericos. Arch. de Hist. Nor. y Pathol.. 3: 317-343. 1946.

14. Duncan, D. If ght and Electron Microscopic Study of Neuroglia in the Normal Spinal Cord of the Rat. Anat. Record, 151: 345. 1965.

15. Eurich, F. Contribution to the Comparative Anatomy of the Neuroglia. J. Anat. Physiol., 32: 688-708. 1898.

16. Farquhar, M.. and Hartmann, J. Neuroglial Structure and Relationships as Revealed by Hectron Microscopy. J. Neuropath.. 16: 18-39. 1957 .

17. Friede, R. The Enzymatic Response of Astrocytes to Varlous Ions in Vitro. J. Cell Biol., 20: 5-15. 1964.

18. The Relationship of Body Size, Nerve Cell Size, Axon Length, and Gilal Dansity in the Cerebellum. Proc. Nat. Acad. Sc1. U.S.A., 49: 187-193. 1963.

19. and Van Houten, W. Neuronal Extension and GIIal Supply. Functional Significance of Glia. Proc. Nat. Acad. Sci. Wash., 48: 817-821. 1962 .

20. Gerschenfeld, $H$. et al. Function of Astoglia in the Water-Ion Metabolism of the Central Nervous System. Neurology, 2: 412 425. 1959.

21. Glees, P. Neuroglia Morphology and Function. C. C. Thomas, Springfield, 1-37. 1955.

22. Hamberger, A. Oxidation of Tricarboxylic Acid Cycle Intermediates by Nerve Cell Bodies and Glial Cells. J. Neurochem., 8: 31-35. 1961.

23. and Hyden, H. Inverse Enzymatic Changes in Neurons and Glia During Increased Function and Hypoxia. J. Cell Biol.. 16: 521-525. 1963.

24. Hawkins, A., and Olszewsiki. J. Glia-Nerve Cell Index for Cortex of the Whale. Science, 126: 76-77. 1957. 
25. Herrick, C. The Morphology of the Forebrain in Amphibia and Reptilita. J. Comp. Neuro., 20: 413-547. 1910.

26. Hoffman, H. The Olfactory Bulb, Accessory Olfactory Bulb and Hemisphere of Some Anurans. J. Comp. Neuro.. 317: 120-121. 1963.

27. Horstmann, E. Die Faserglia des Selachiergeherns. Zeit. fur Zell. und Mkro. Anat., 38: 588-617. 1953-54.

28. Hortega, P. del Rio. Ia Neuroglia Normal, Conceptos de Anglogliona y Neurogliona. Arch, de Hist. Nor. y Path., 1: 5-71. 1942.

29. El Metodo del Carbonato Axgentico: Revision General de sus Tecnicas y Aplicaciones on Histologia Normal y Patologica. Arch. de Hist. Nor. y Path., 1: 165-206, 329-362. 1942.

30. El Metodo del Carbonato Argentico: Reviston General do sus Tecnicas y Aplicaciones on Histologia Normal y Patologlca. Arch. de Hist. Nor. I Path., 1: 231-244, 577-604. 1943.

31. Hosokawa, H., and Hajime, M. Some Aspects of the Histology of Neuroglia. In: Morphology of Nouroglia. Ed. J. Nakai. C.C. Thomas, Springfield, 1-52. 1963.

32. Huber, G. Studies on the Neuroglia in Vertebrates. Am. J. Anat., 1: $45-61.1903$.

33. Johnson, J. The Telencephalon of Ganolds and Teleosts. J. Comp. Neuro., 21: 489-591. 1911.

34. Kappers, A., Huber, C.. and Crosby, E. The Comparative Anatomy of the Nervous System Including Man. Vol. III. Hafner. New York. 1256-1455, 1477-1485. 1936.

35. Lumsden, C., and Pomerat, C. Normal Oligodendrocytes in Tissue Culture. J. Exp. Cell. Res.. 2: 103-114. 1951. 36. Mulier, E. Studien uber Neuroglia. Arch. Mikro. Anat., 60: 11-

37. Osorio, H. Bases Anatomicas de la Unidad Functonal Neurona Glia. Antioquia Medica, 14: 275-284. 1964. 
38. Pannese, E. Recherches Anatomo-Comparatives et Morphogenetiques sur la Neuroglie de la Moelle Epiniere des Vertebres. Compt. Rend. Assoc. Anat., 44: 561-568. 1958.

39. Papez, J. Comparative Neurology. Hafner, New York. 11, 387478. 1929.

40. Penfield, W. Oligodendroglia and its Relation to Classical Neurogiia. Brain, 47: 430-452. 1924.

41. Neuroglia and Microglia. The Interstitial Tissue of the Central Nervous System. In: Special Cytology. Vol. II. Ed. E. Cowdry. Hoeber, New York. 1031-1065. 1928.

42. Neuroglia, Normal and Pathological. In: Cytology and Celluiar Pathology of the Nervous System. Vol. II. Ed. W. Penfield. Hoeber, New York. 421-472. 1932.

43. Peters, A. Plasma Membrane Contacts in the Central Nervous System. J. Anat., 26: 237-248. 1962.

44. Pomerat, C. Dynamic Neurogliology. Tex. Report Biol, and Med., 10: $885-913.1952$.

45. - Functional Concepts Based on Tissue Culture Studies of Neuroglia Cells. In: Biology of Neuroglia. Ed. W. Windle. C.C. Thomas, Springfield. 162-175. 1958.

46. Ramon-Moliner, E. A Study of Neuroglia: The Problem of Transitional Forms. J. Comp. Neuro., 110(2): 157-165. 1958.

47. Scharenberg, $K$. The Silver Carbonate Technique for the Impregnation of the Astroglia. J. Neuropath. and Nop. Neurol., 19: 622-627. 1960.

48. Scheibel, M., and Scheibel, A. Neurons and Neuroglia Cells as seen with the Light Microscope. In: Biology of Neuroglia. Ed. W. Windle. C.C. Thomas, Springfleld. 5-23. 1958. 
Fig. 1. Flsh. Photomicrograph of opendymal cells and processes in the forebrain. $400 \mathrm{X}$

Arrow indicates the union of three processes into a larger bundle.

Fig. 2. Flsh. Photomicrograph demonstrating sparcity of autonomous glial elements. $640 \mathrm{X}$

e ependymal cell processes

n neuron

Flg. 3. Flsh. Photomicrograph of bipolar glial cell with its cell body related to a blood vessel and a process related to a nouron. $640 x$

bv blood vessel

g nouroglia

n nouron

FIg. 4. Fish. Photomicrograph of typical bipolar glial cell in the forebrain. $600 \mathrm{x}$

Arrow Indicates bipolar cell 


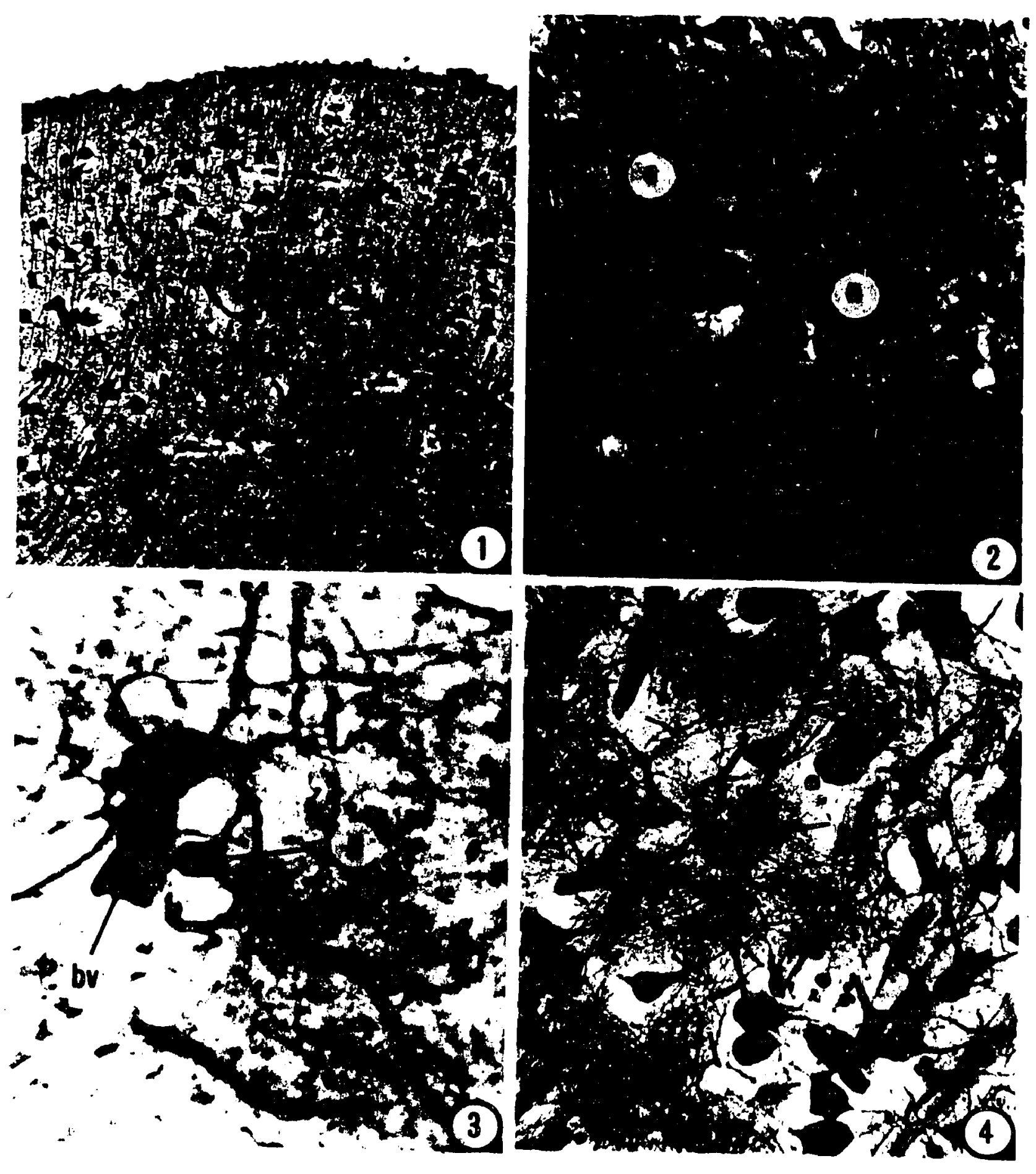


Fig. 5. Frog. Photomicrograph of presumptive hippocampal region demonstrating neurons and ependymal cell processes. $160 \mathrm{X}$

Flg. 6. Frog. Photomicrograph demonstratting tripolar glial cell with secondary branching of processes. $400 \mathrm{X}$

g neuroglia

Flg. 7. Frog. Photomicrograph of presumptive basal ganglia region with neuroglial vascular endings wrapped around a blood vessel. $500 \mathrm{x}$

br blood vessel

g neuroglia

Fig. 8. Frog. Photomicrograph of a glial cell body on a vessel with a single process directed toward a neuron. $400 \mathrm{X}$

bv blood ressel.

g nouroglia

n nouron

Flg. 9. Frog. Photomicrograph of a tripolar glial cell with one process directed toward a neuron. $400 \mathrm{X}$

g neuroglia

n neuron

Fig. 10. Frog. Photomicrograph of glial cell bodies related to a blood vessel. Note secondary branchings of the single process directed away from the vessel. 500X

bv blood vessel

g nouroglia

n nouron 

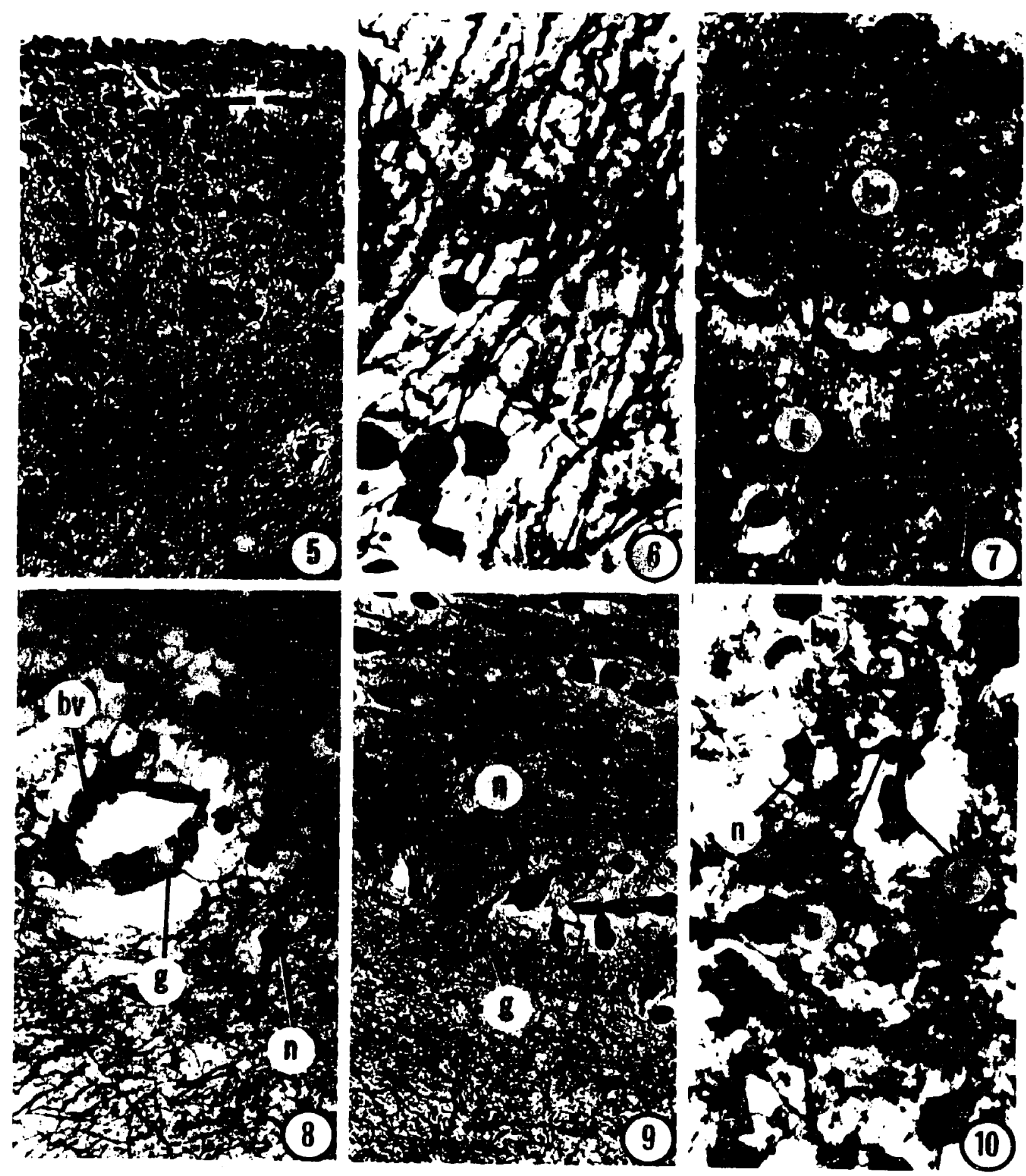
Fig. 11. Iizard. Photomicrograph of presumptive hippocampal region. Note glial cell with fine processes directed toward a neuron. $600 x$

g neuroglia

$n$ neuron

Fig. 12. Itzard. Photomicrograph of glial cell showing different thicknesses of processes and secondary branchings of main cellular processes. $400 \mathrm{X}$

g neuroglia

Fig. 13. Iizard. Photomicrograph of marginal autonomous neuroglia with processes directed toward free surface of presumptive hippocampal area. $400 \mathrm{X}$

g neuroglia

Fig. 14. Lizard. Photomicrograph of ependymal process and process of a free glial cell related to a neuron. 500x
- ependymal cell process
B neuroglia
n nouron

Fig. 15. Lizard. Photomicrograph of basal ganglia region. Note vascular ending and bipolar glial element. $600 \mathrm{x}$

bv blood vessel

g neuroglia

v vascular ending

Fig. 16. Lizard. Photomicrograph of presumptive hippocampal region demonstrating elongated ependymal cell processes. $200 \mathrm{X}$

e ependymal cell processes 


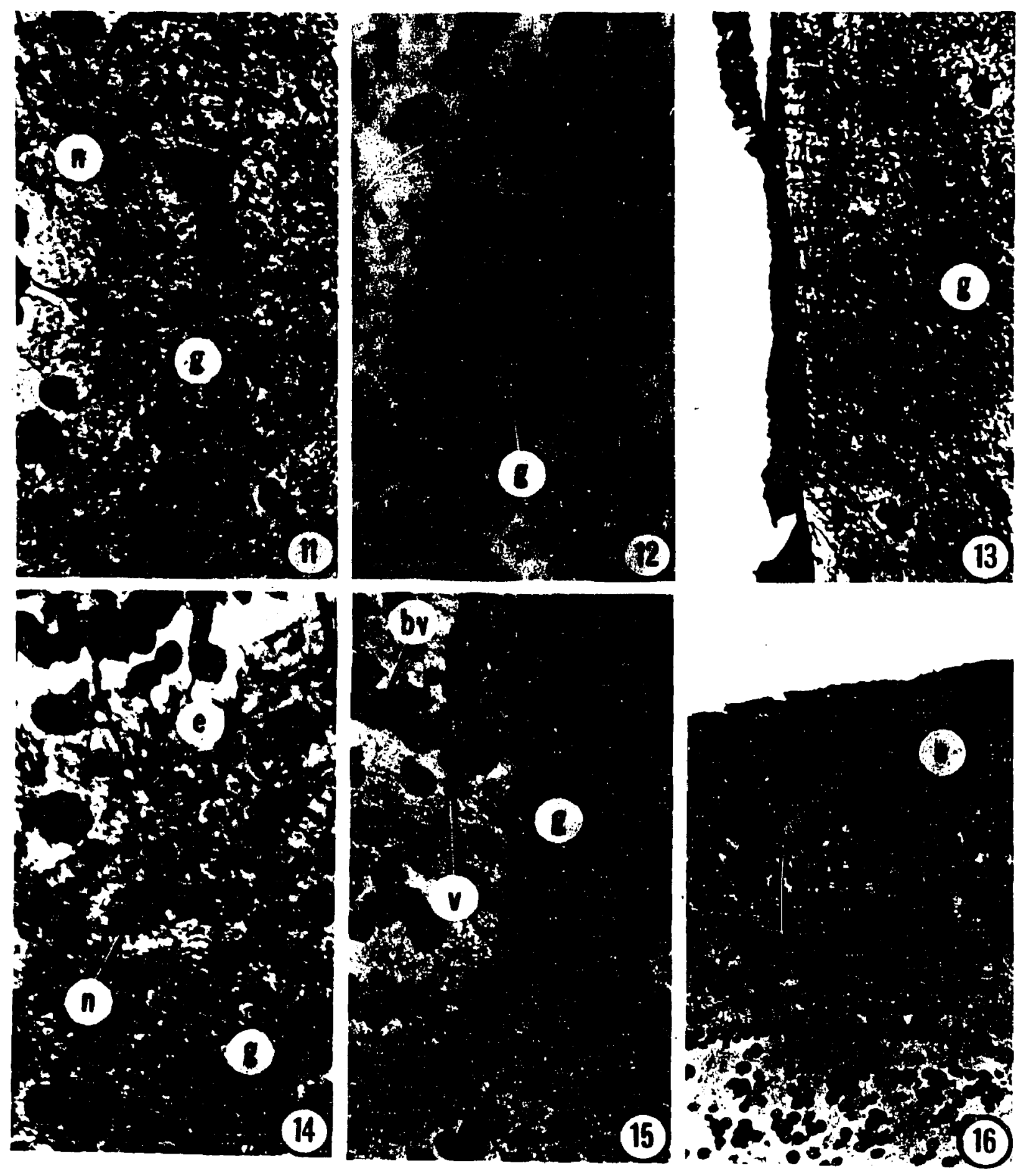


Fig. 17. Bird. Photomicrograph of thick and thin processes related to a blood vessel. $1100 \mathrm{X}$

bv blood vessel

p thin processes of an astrocyto

$t$ thick processes of an astrocyte

v vascular ending

Fig. 18. Bird. Photomicrograph of the basal ganglia demonstrating neuroglia, neuron relationships. $500 \mathrm{X}$

Arrow indicates astrocyte process related to nouron

n neuron

3 astrocyte with round cell body

Fig. 19. Bird. Photomicrograph demonstrating glial variation in the basal ganglia. $400 \mathrm{X}$

a typical stellate astrocyte

- oligodendrocyte

$s$ astrocyte with round cell body

tr transitional cell

FIg. 20. Bird. Photomicrograph of glial variation and neuroglia related to neuroglia. $400 \mathrm{X}$

a typical stellate astrocyte

b a glia cell process related to a glia cell bod 

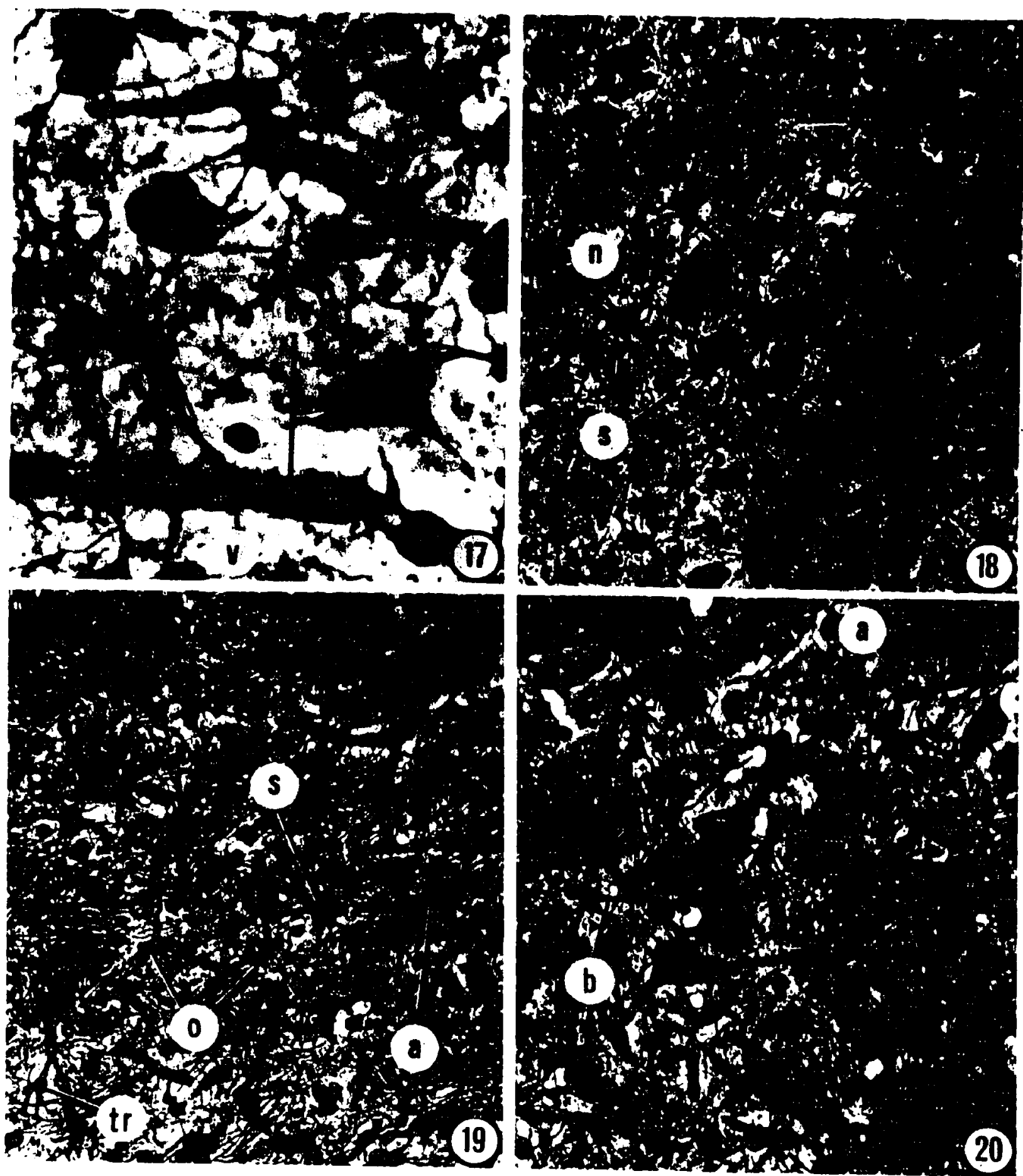
Fig. 21. Bird. Photomicrograph of non-ependymal neuroglia in the hippocampal region. 500X

Arrows indicate non-ependymal bipolar and tripolar neuroglia

n neuron

Fig. 22, Bird. Photomicrograph of ependymal cells in hippocampal region. Note bipolar glial cell. 400X

Arrow bipolar glial cell

- ependymal cell process

n nouron

Fig. 23. Bird. Photomicrograph to demonstrate the close association of neuroglia and the neurons of the basal region. $700 \mathrm{X}$

d a glia cell process related to a neuron

Fig. 24. Bird. Photomicrograph of basal ganglia demonstrating glia to glia relations and variations of cell types. $500 \mathrm{X}$

a typical stellate astrocyte

b a glia cell process related to a glia cell body

$s$ astrocyte with round cell body 

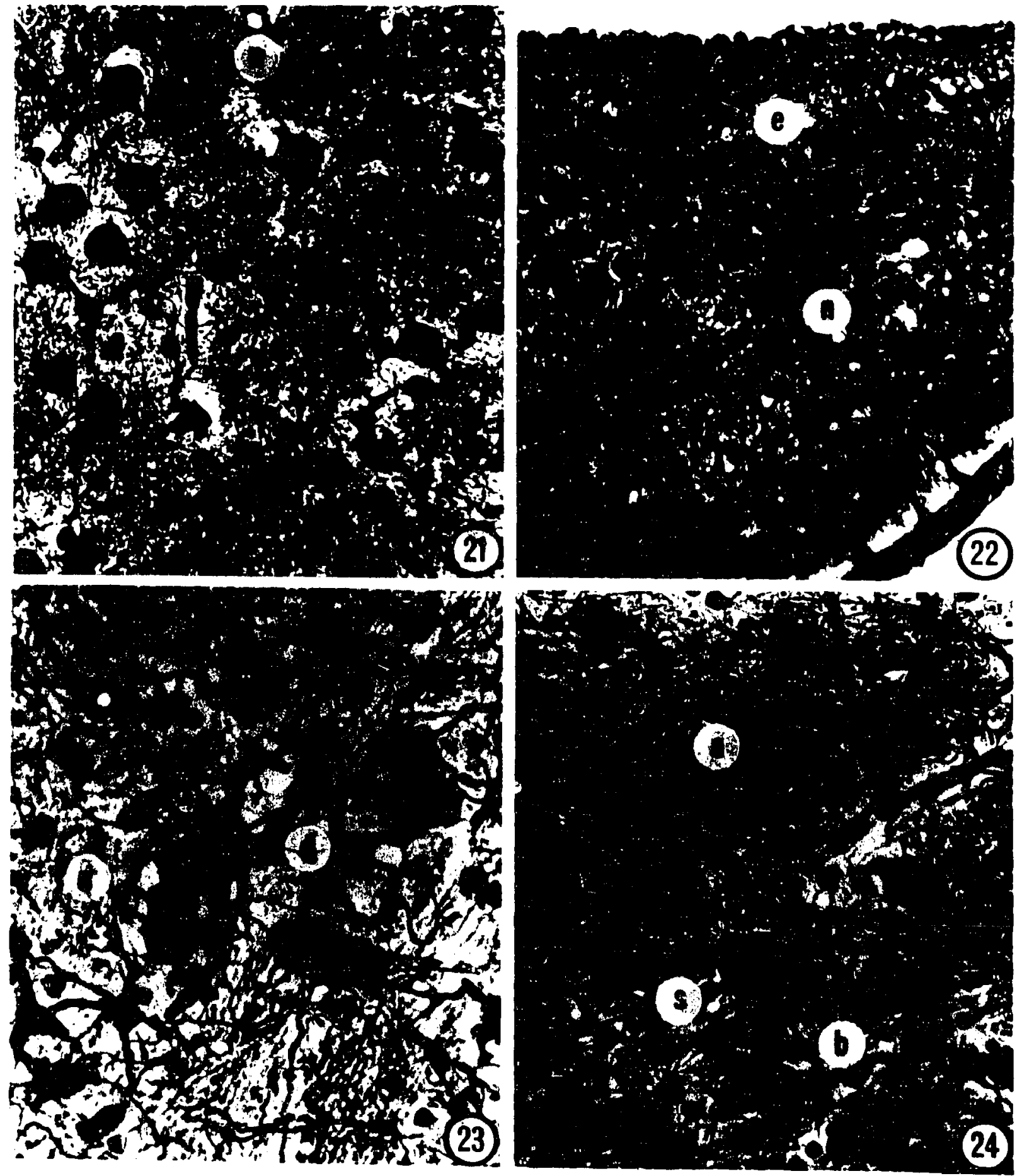
Fig. 25. Opossum. Photomicrograph of oligodendrocytes in subcortical white matter. $400 \mathrm{X}$

- oligodendrocyte

FIg. 26. Opossum. Photomicrograph of an astrocyte with a round cell body related to a blood vessel in the marginal cortex. $500 x$

bv blood vessel

s astrocyte with round cell body

Fig. 27. Opossum. Photomicrograph of an astrocyte with thick and thin processes in the hippocampus. $600 \mathrm{X}$

s astrocyte with round cell body

Fig. 28. Opossum. Photomicrograph of an astrocyte with thick and thin processes in the dentate gyrus. $800 \mathrm{X}$

$s$ astrocyte with round cell body

Fig. 29. Opossum. Photomicrograph of typical astrocyte in subcortical white mattor. $700 \mathrm{X}$

a typical stellate astrocyto

Fig. 30. Opossum. Photomicrograph of lamellar forms of astrocytes in subcortical white matter. $400 \mathrm{X}$

1 lamellar astrocyto 

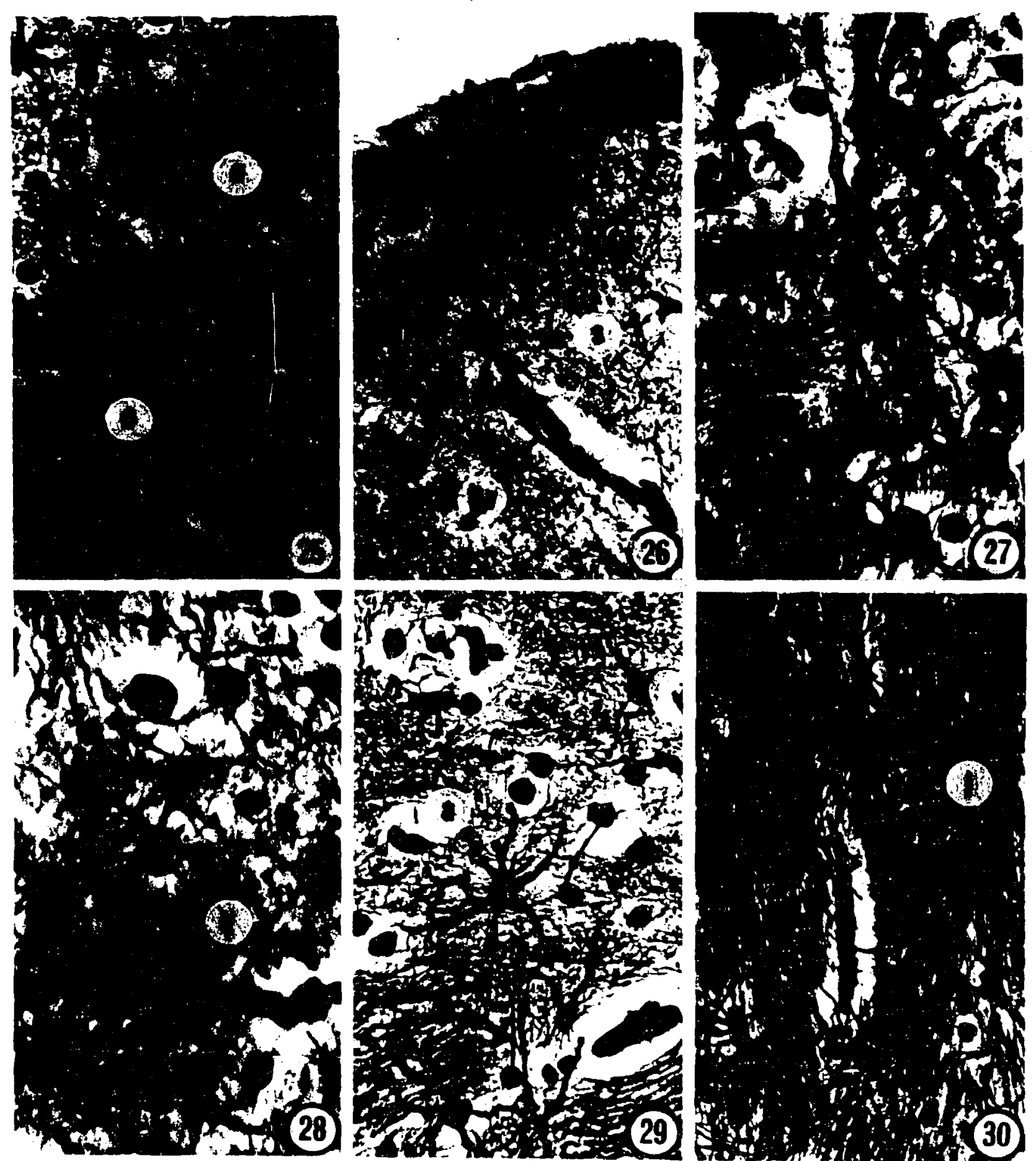

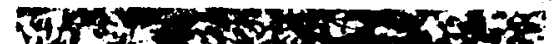
1) 10 and (s)

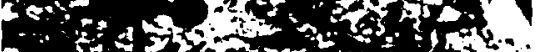

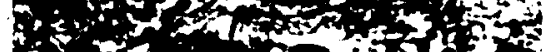

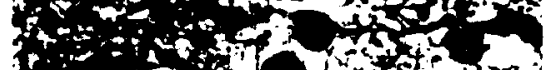
$7-1+0\}$

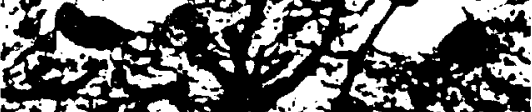

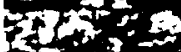

$5-3=-x=170 \%$ astons and (n)

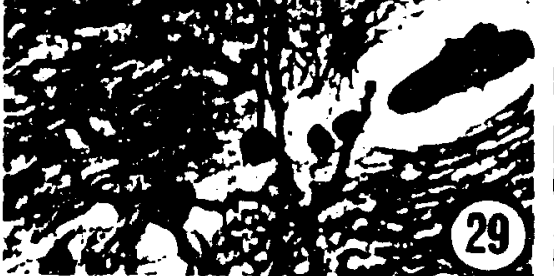

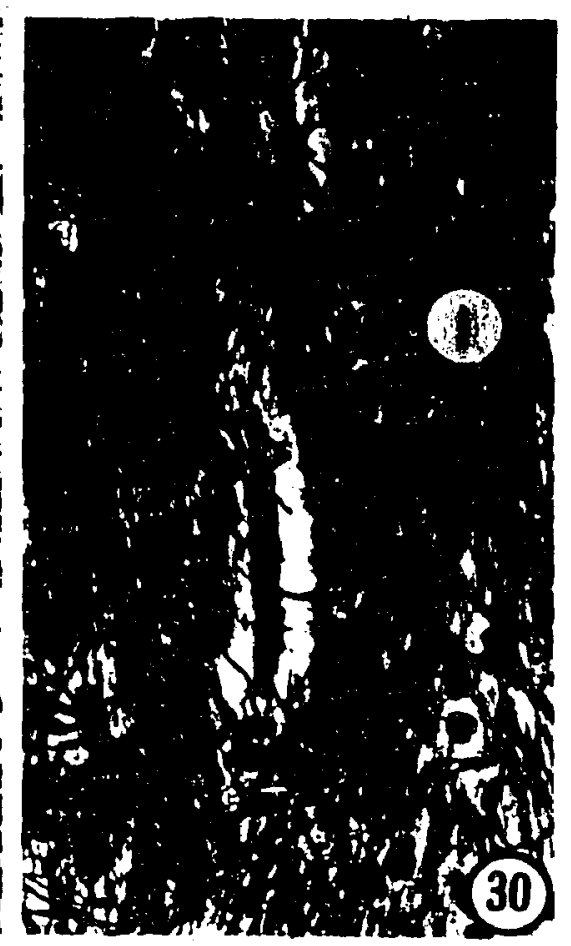


Fig. 31. Opossum. Photomicrograph of an astrocyte with its processes oriented toward the dendritic trunk of the pyramidal cells in the hippocampus. E0cX.

Arrow indicates astrocyte related to axon

dt dendritic trunk

n neuron

$s$ astrocyte with round cell body

Fig. 32. Opossum. Photomicrograph of an astrocyte related to an astrocyte and astrocyte processes related to the processes of neurons in the hippocampus. $500 \mathrm{X}$

Arrows indicate astrocyte processes that are related to axons

c an astrocyte cell body related to another astrocyte cell body dt dendritic trunk

Fig. 33. Opossum. Photomicrograph of a glial cell in contact with a neuron cell body with a large area of cell membrane contact. $1000 x$

d a glia cell process related to a neuron

n nouron

Fig. 34. Opossum. Photomicrograph of neuroglia in the dentate gyrus. Note astrocyte related to astrocyte and the enlarged terminal process of an astrocyte found in close approximation to a neuron. $500 \mathrm{X}$

b a glia cell process related to a glia cell body

d a glia cell process related to a neuron

n nouron 

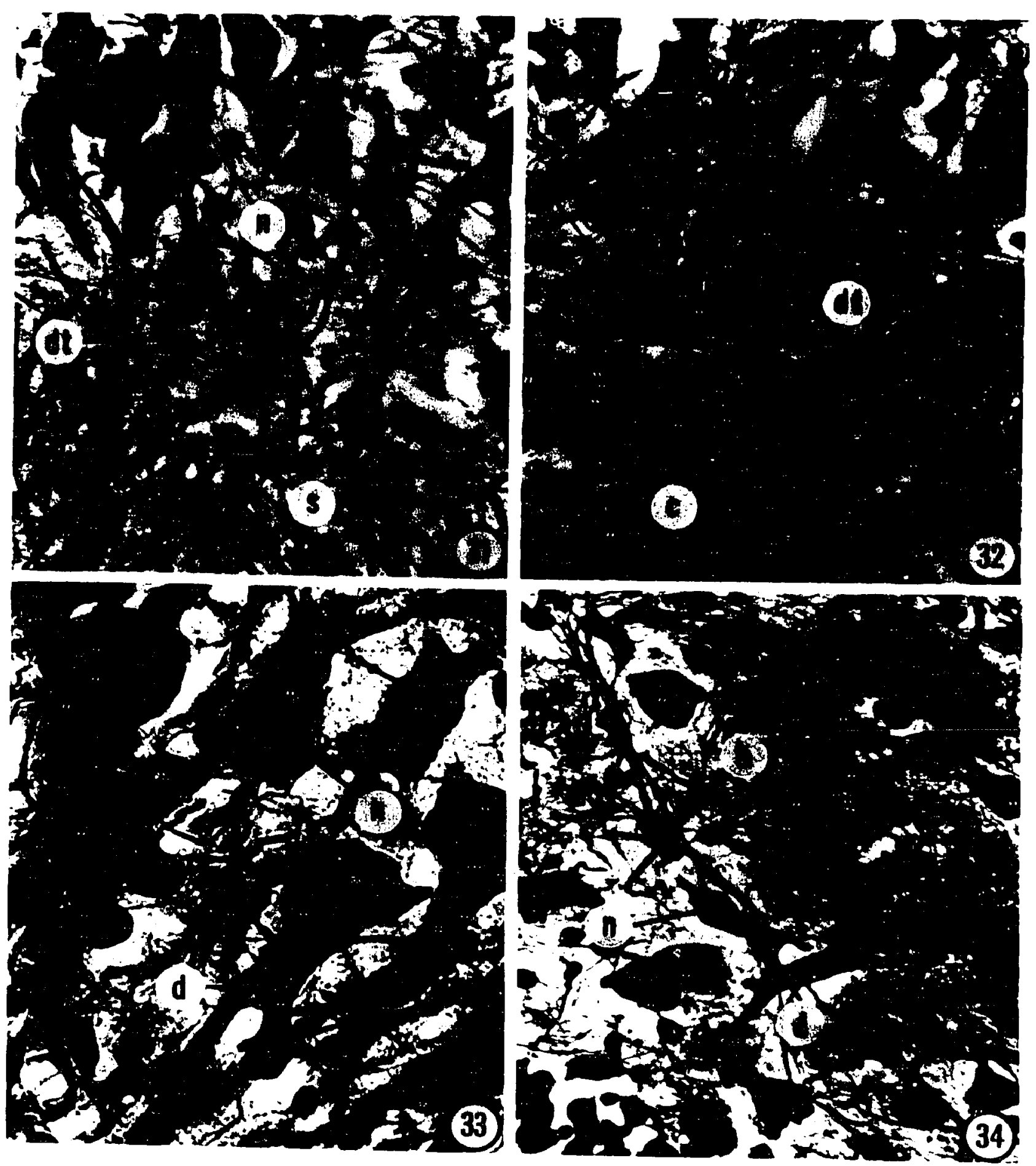
F1g. 35. Opossum. Photomicrograph of an astrocyte in neom cortex. $500 \mathrm{X}$

Arrows indicate processes of astrocyte related to neurons

n neuron

Fig. 36. Opossum. Photomicrograph of glia neuron relationship in the caudate nucleus. $500 \mathrm{X}$

n nouron

$s$ astrocyte with round cell body

Fig. 37. Opossum. Photomicrograph of marginal layer of the dentate grus. 200X

$s$ astrocyte with round cell body

Flg. 38. Opossum. Photomicrograph of marginal layer of neocortex. $240 x$

$s$ astrocyte with round cell body 

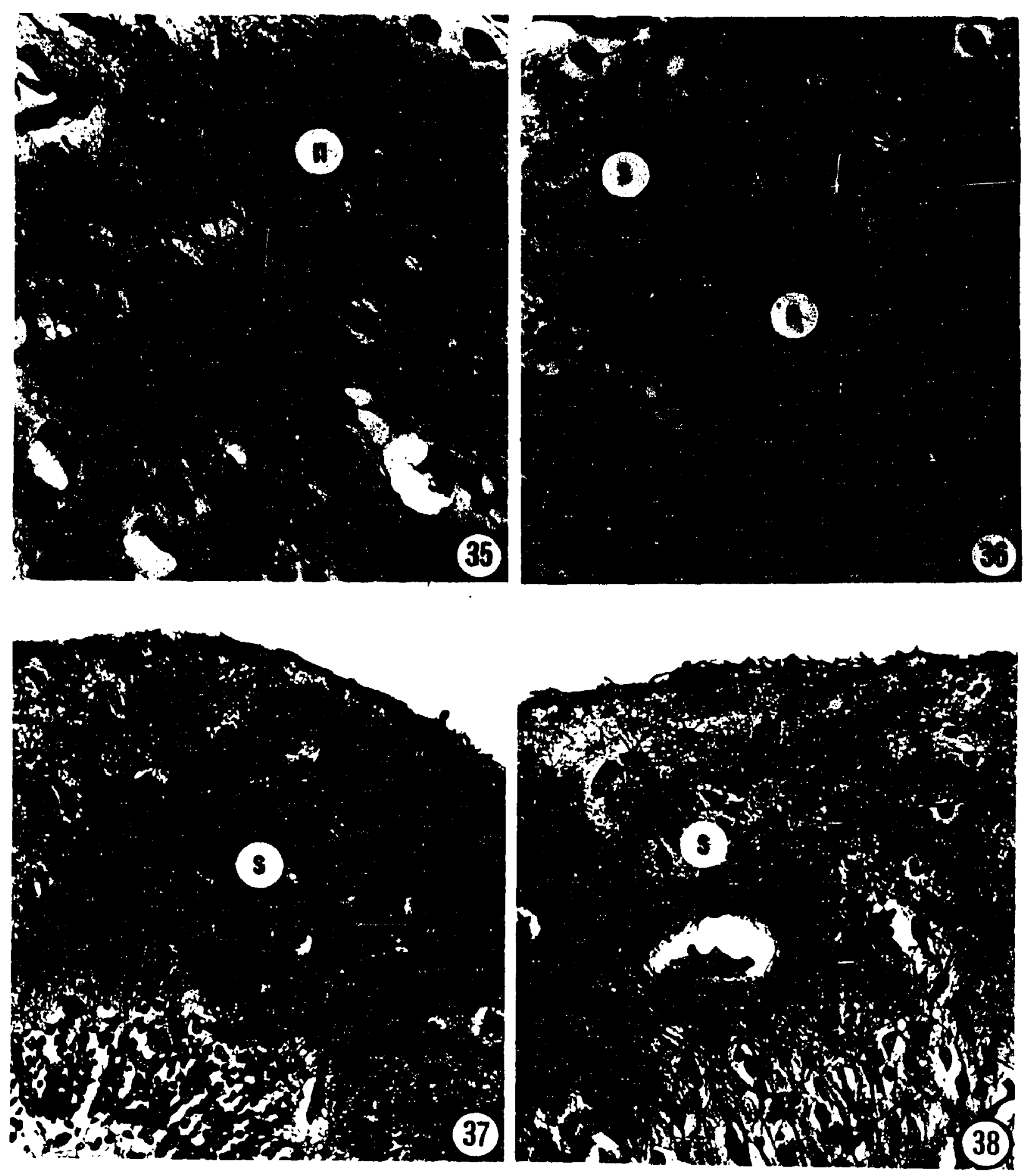
Fig. 39. Horse. Photomicrograph demonstrating thick processes of an astrocyte with an end foot on a blood vessel. 700x

a typical stellate astrocyte

bv blood ressel

$t$ thick processes of an astrocyte

Fig. 40. Horse. Photomicrograph demonstrating thin processes of a large astrocyte directed toward a blood vessel in the precentral gyrus. $480 \mathrm{X}$

a typical stellate astrocyte

bv blood vessel

p thin processes of an astrocyte

Fig. 41. Horse. Photomicrograph of the caudate nucleus demonstrating an astrocyto with its processes directed toward two different nourons and its cell body related to the cell body of an oligodendrocyte. Note ring of oligodendrocytes around the neuron and the approximation of their cell bodies to each other. $700 \mathrm{X}$
aa astrocyte
n neuron
- oligodendrocyte

Fig. 42. Horse. Photomicrograph of precentral gyrus that shows astrocyte processes related to the cell bodies of oligodendrocytes. $480 \mathrm{X}$

Arrow indicates astrocyte process related to oligodendrocyte cell body a typical stellate astrocyte

Fig. 43. Horse. Photomicrograph of satellite cells around the cell bodies of pyramidal cells of the hippocampus. 500X

d a glia cell process related to a neuron 


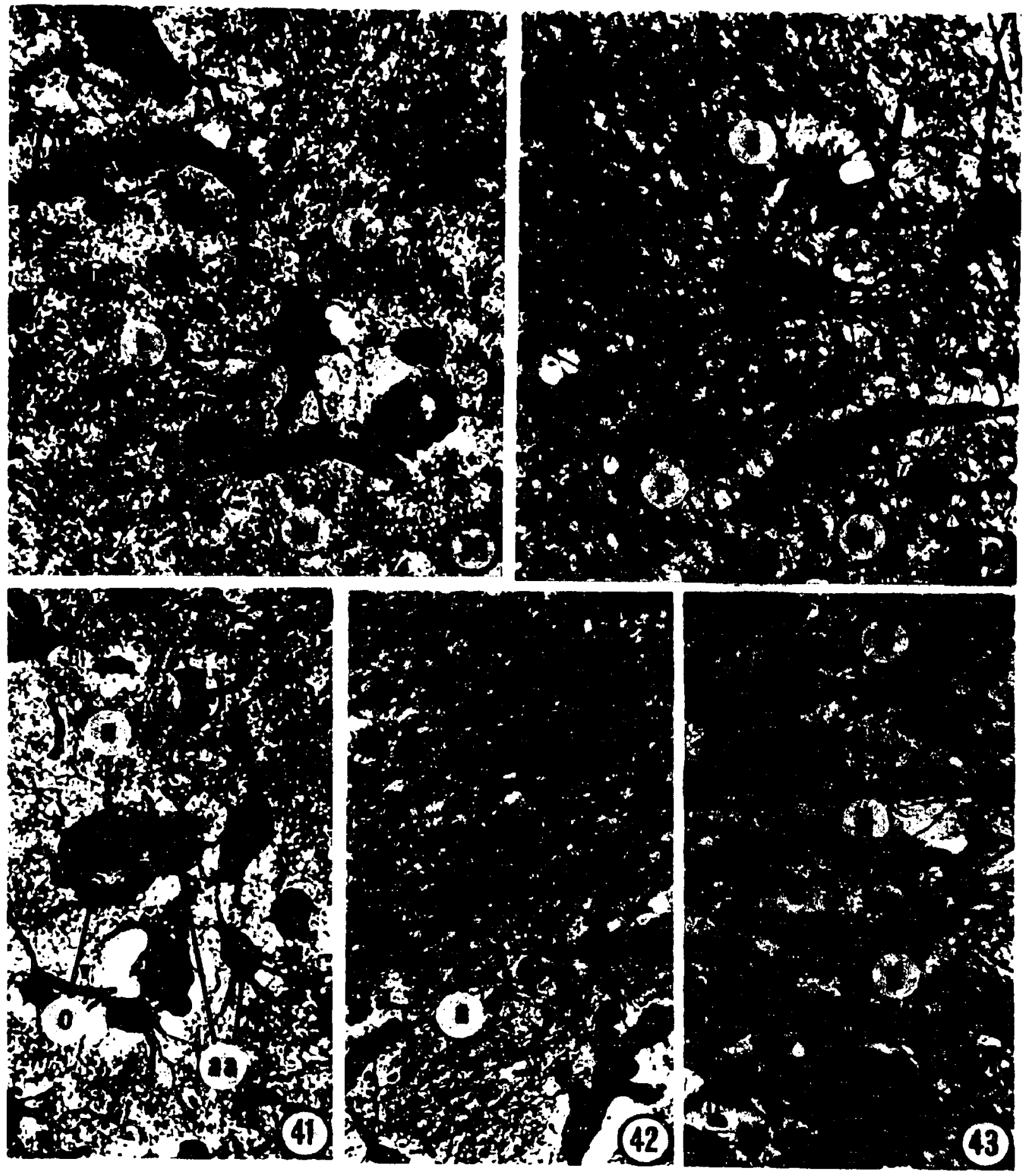


Fig. 44. Horse. Photomicrograph of a caudate nucleus that demonstrates astrocytes related to astrocytes by their processes and the approximation of their cell bodies. Also note astrocyte processes related to neurons and blood vessels. $800 \mathrm{X}$

a typical stellate astrocyte

br blood vessel

f an astrocyte process related to an astrocyte cell body

j an astrocyte process related to a neuron

n neuron

Fig. 45. Horse. Photomicrograph of the lentiform nucleus with small astrocytes related to neurons via fine processes. $400 \mathrm{X}$

d a glia cell process related to a neuron

Fig. 46. Horse. Photonicrograph of the precentral gyrus with an astrocyte interposed between a blood vessel and a neuron. $400 \mathrm{X}$

a2 astrocyte

bv blood vessel

n neuron

Flg. 47. Horse. Photomicrograph of marginal cortex showing perivascular glia cells. 480X

Arrows indicate cell bodies of astrocytes related to the wall of a blood vessel.

bv blood vessel 

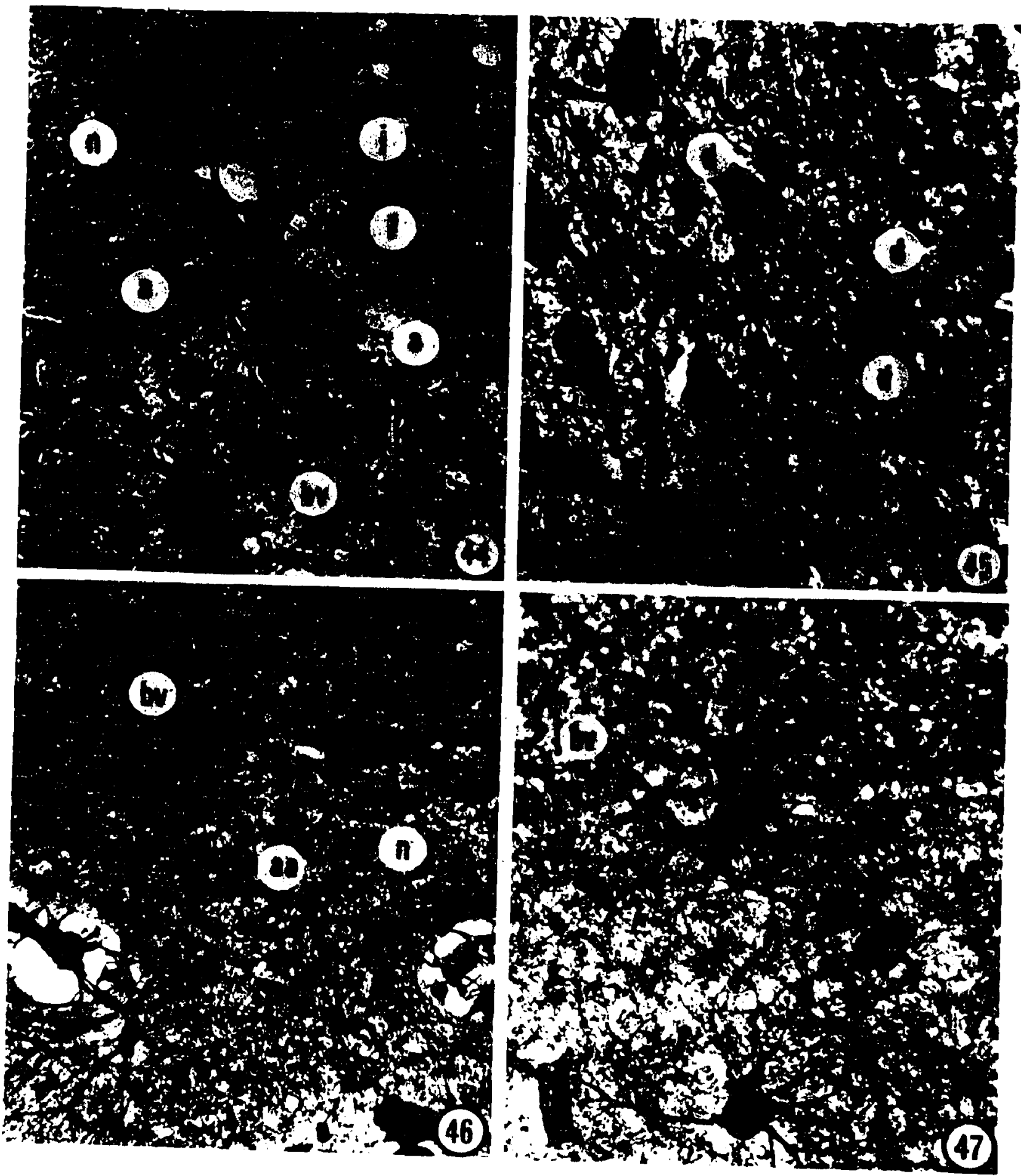
Flg. 48. Horse. Photomicrograph from hippocampal-dentate gjrus area demonstrating astrocyte processes related to each other, and oligodendrocyto processes related to each other with an apparent increase in surface area at the point of contact. $3500 \mathrm{X}$

h an oligodendrocyte process related to an oligodendrocyte process with an apparent increase in surface area

1 an astrocyte process related to an astrocyte process

- oligodendrocyte

$s$ astrocyte with round cell body 
65

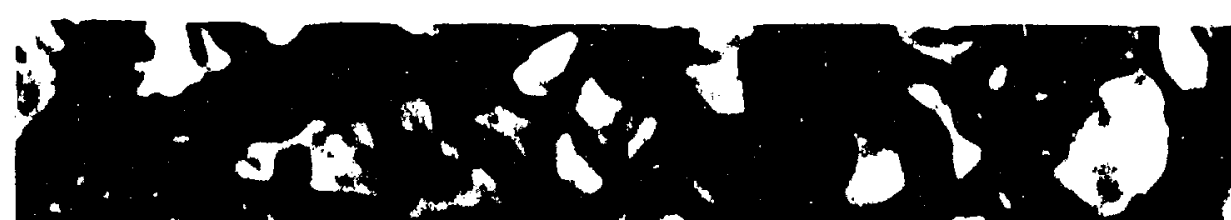

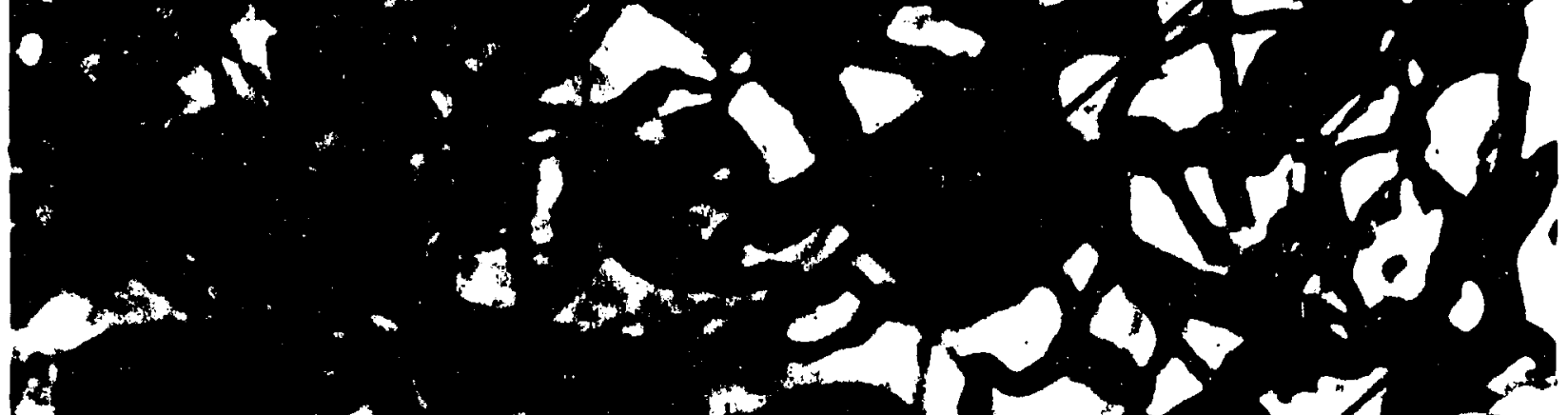

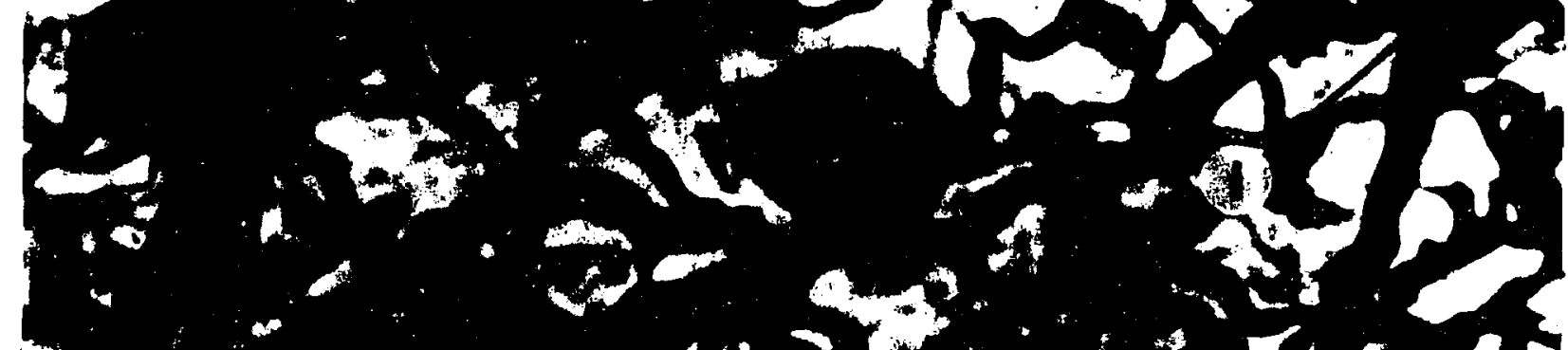

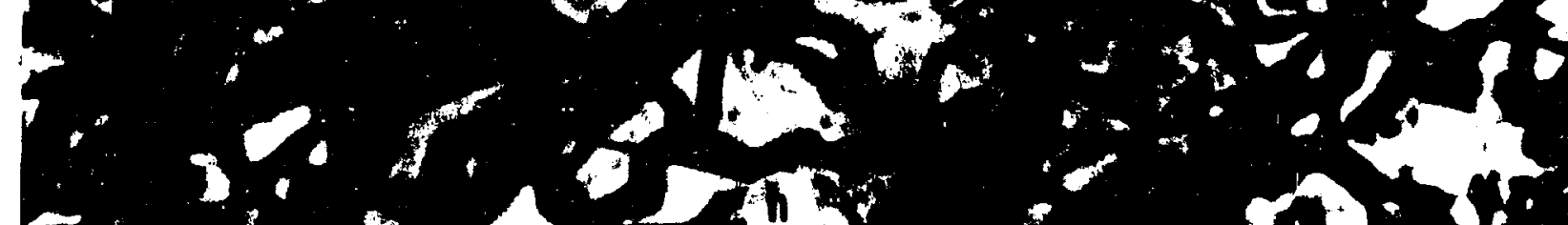

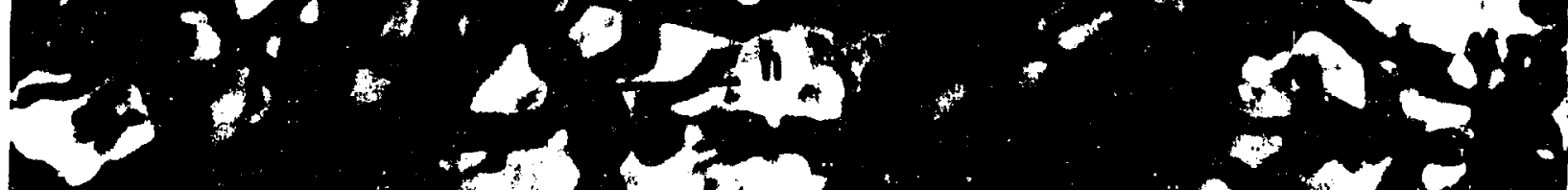

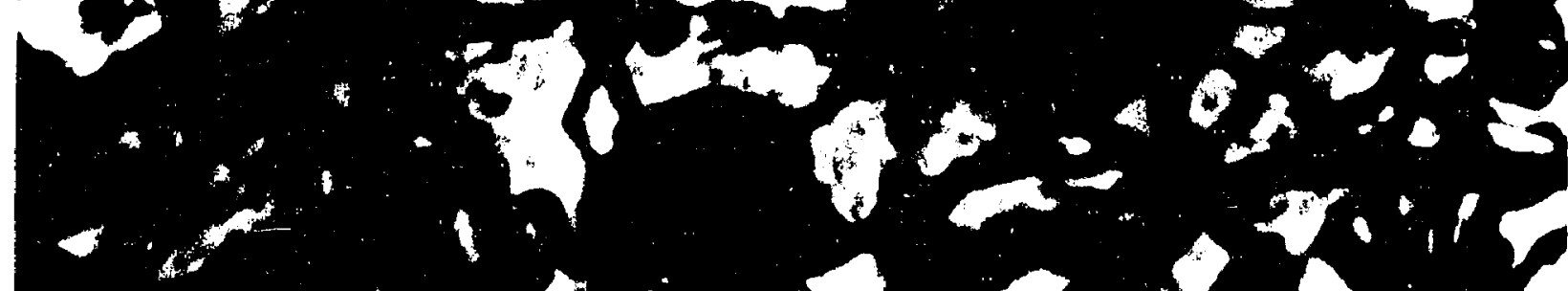
$\therefore$ a

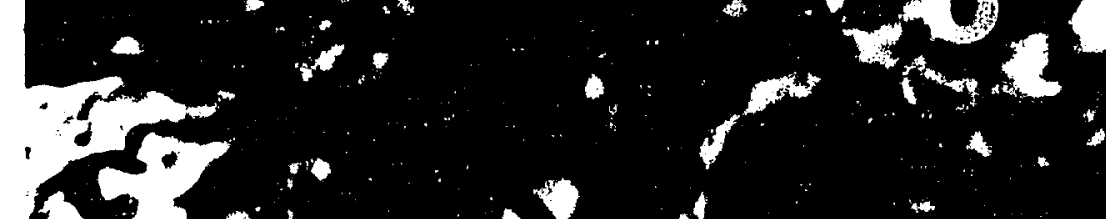

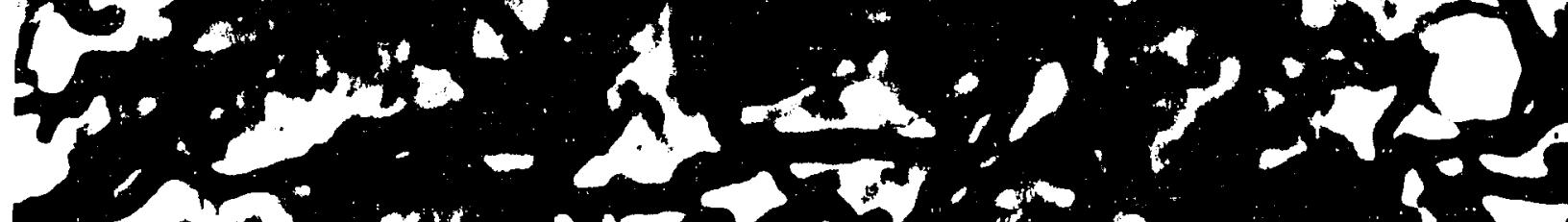

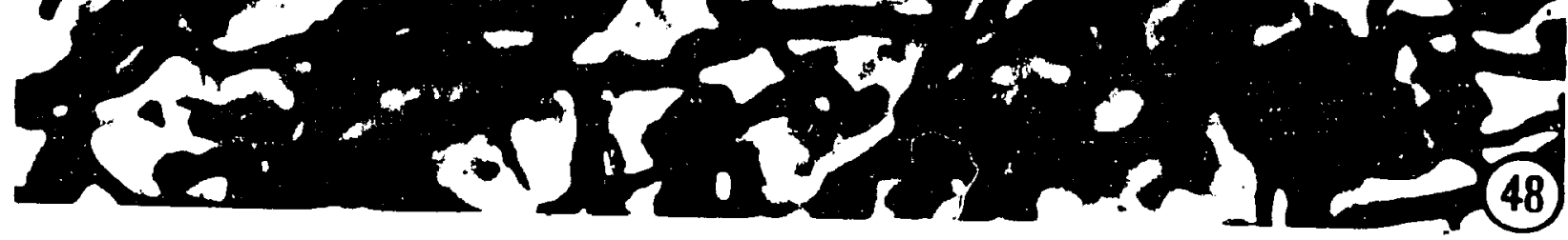


Flg. 49. Monkey. Photomicrograph of marginal cortex to demonstrate variations in the muber of processes in astrocytes with round cell bodies. $600 \mathrm{x}$

a typical stellate astrocyte

- oligodendrocyte

F1g. 50. Monkey. Photomicrograph of middle cortical layers showing neuroglia related to the cell bodies and processes of neurons. $400 x$

aa astrocyte

n nouron

FIg. 51. Monkey. Photomicrograph of deep cortex demonstrating astrocytes with thicker processes as compared to the more superficial cortical layers. $400 \mathrm{x}$

aa astrocyte

$t$ thick processes of an astrocyte

Fig. 52. Monkey. Photomicrograph of deep layers of cortex that shows typical large astrocyte forms with heavy, thick processes. Note wrap around vascular attachment. 640X

bv blood vessel

n nouron

$t$ thick processes of an astrocyte

$\checkmark$ vascular attachment 

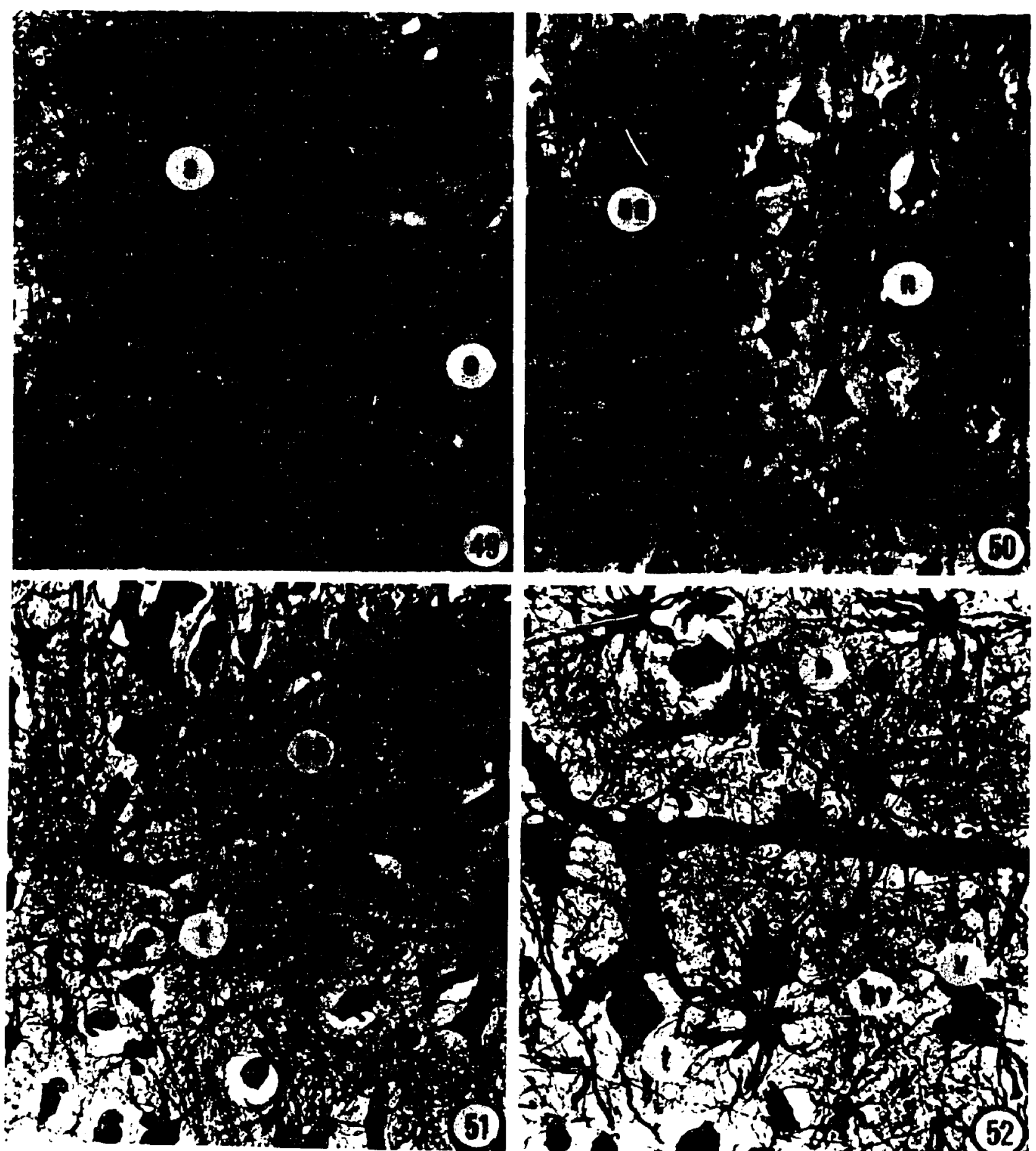

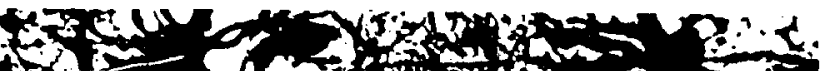

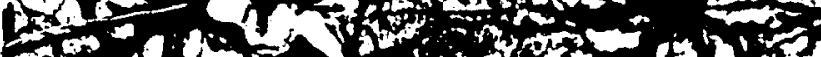

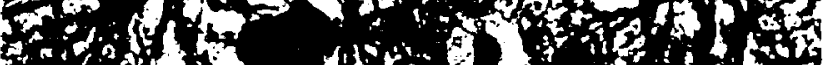

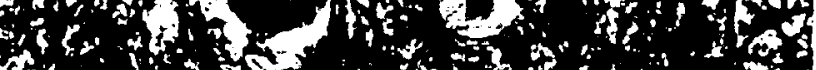

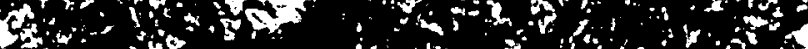

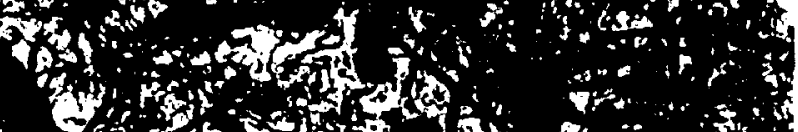

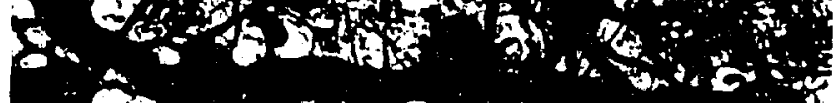

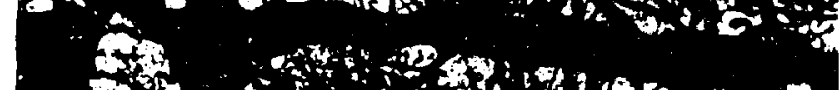

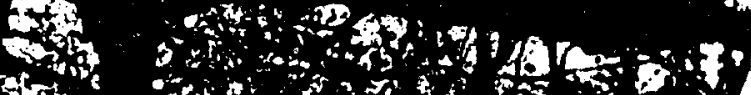

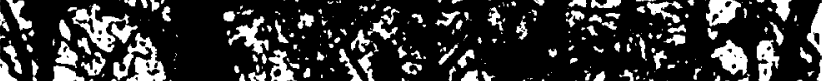

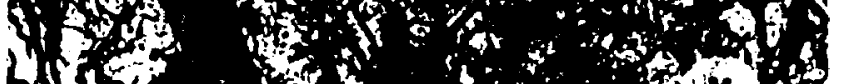

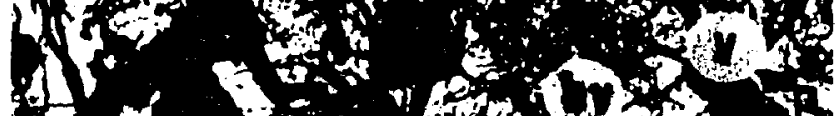
Th

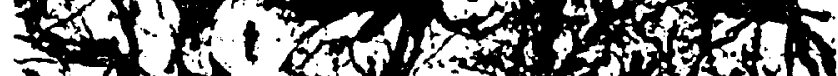

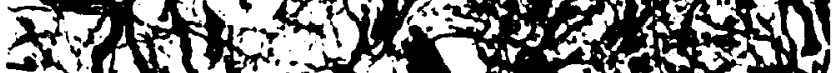

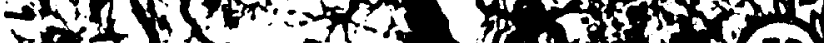

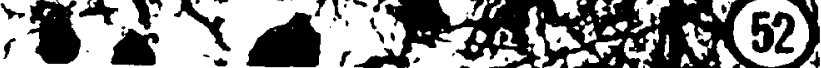


Flg. 53. Monkey. Photomicrograph of linear arrangement of astrocytes just deep to the gray matter of the precentral gyrus. $400 \mathrm{X}$

Fig. 54. Monkey. Photomicrograph of the caudate nucleus demonstrating astrocyte, blood vessel, and neuron relationshtp. Iote the close association of the processes of astrocytes and the size of the astrocytes compared to the neurons. $400 \mathrm{X}$
22 astrocyto
2 typical stellate astrocyte
bv blood vessel
n neuron

Fig. 55. Monkey. Photomicrograph of caudate nucleus deannstrating the processes of astrocytes related to the cell body of an astrocyte and to neurons. Note size of astrocytes as compared to neuron size. $600 \mathrm{X}$
1 an astrocyte process related to an astrocyte cell body
j an astrocyte process related to a neuron
n neuron

Fig. 56. Monkey. Photomicrograph of the globus pallidus which has generaliy larger neurons than the caudate but smaller glial cells. $500 \mathrm{x}$

n neuron 


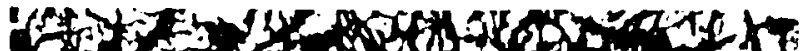

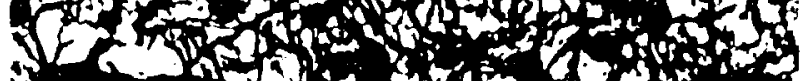
To he

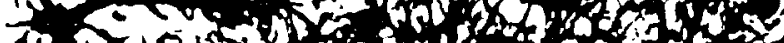

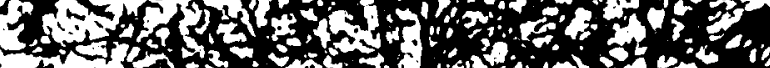

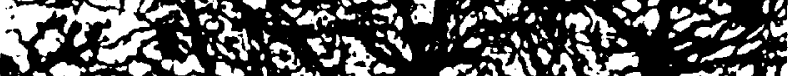

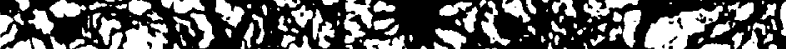

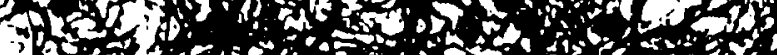

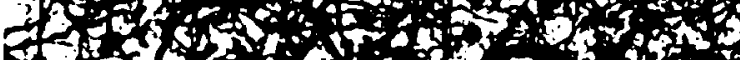

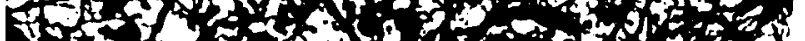

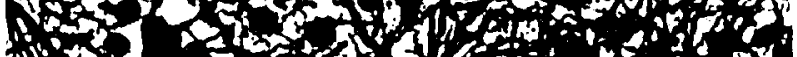

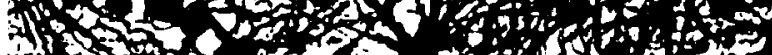

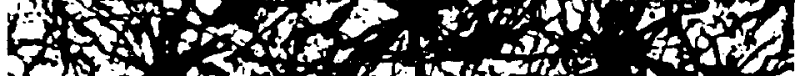

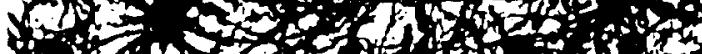

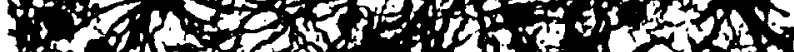
- SA

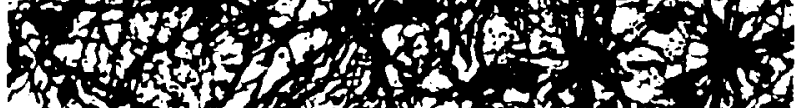
2) 1 \%

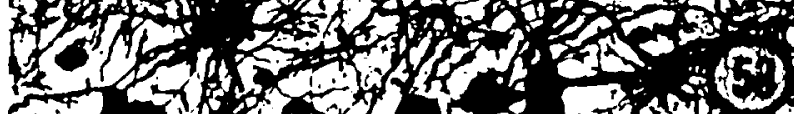
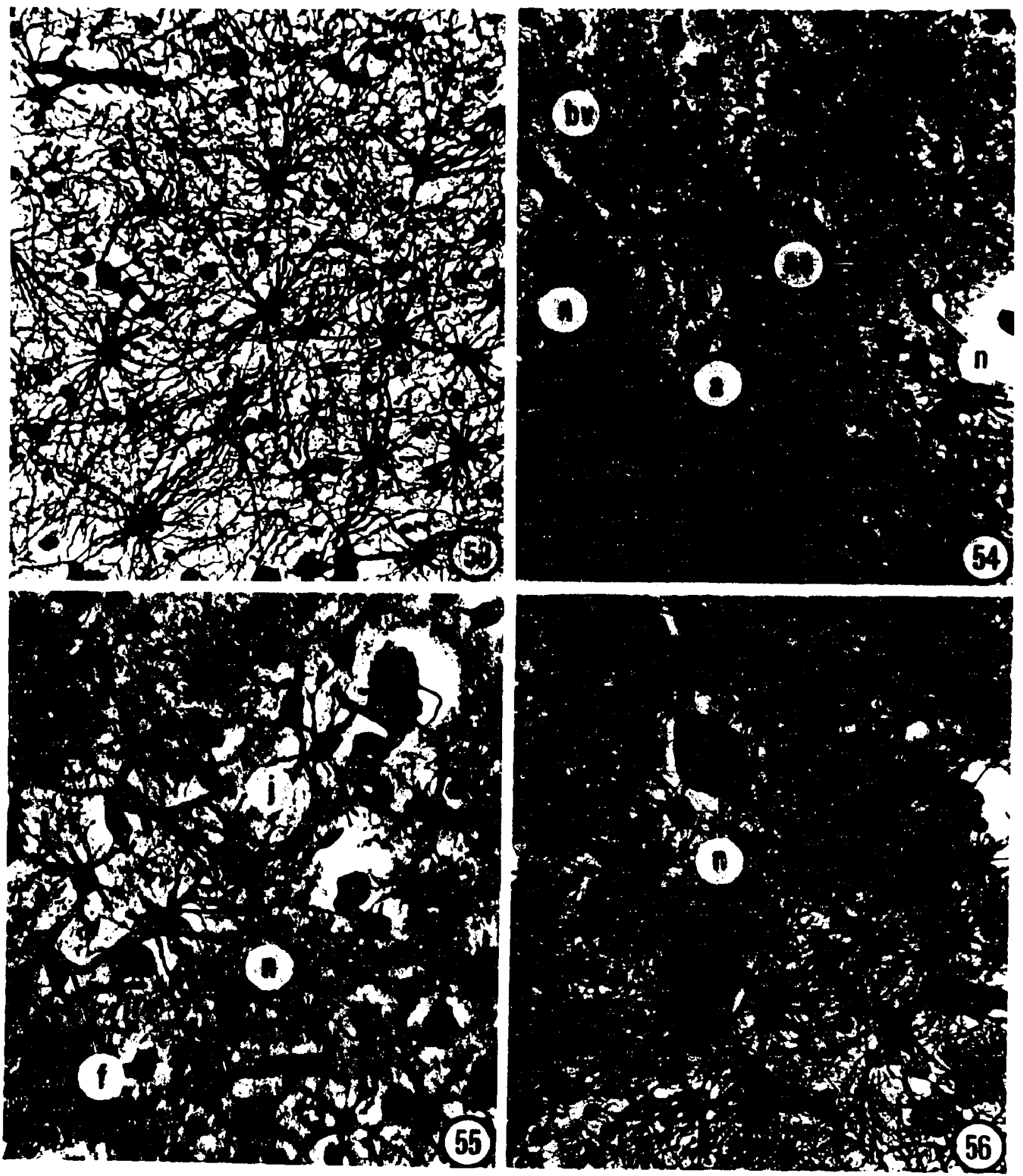
Fig. 57. Monkey. Photomicrograph of area where hippocampus pyramidal cell layer blends with the dentate gyrus. 100X

y pyramidal cell layer of the hippocampus

z granule cell layer of the dentate gyrus

Flg. 58. Monkey. Photomicrograph of pyramidal cell layer of the hippocampus with astrocytes oriented to axons. 160X

y pyramidal cell layer of the hippocampus

Fig. 59. Monkey. Photomicrograph of the dentate gyrus demonstrating astrocyte variation in cell size and number of processes. $500 \mathrm{X}$

$s$ astrocyte with round cell body

$j$ an astrocyte process related to a neuron

Fyg. 60. Monkey. Photomicrograph of dentate gyrus demonstrating an increase in glial processes as compared to the opossum and the horse. $400 \mathrm{X}$ 

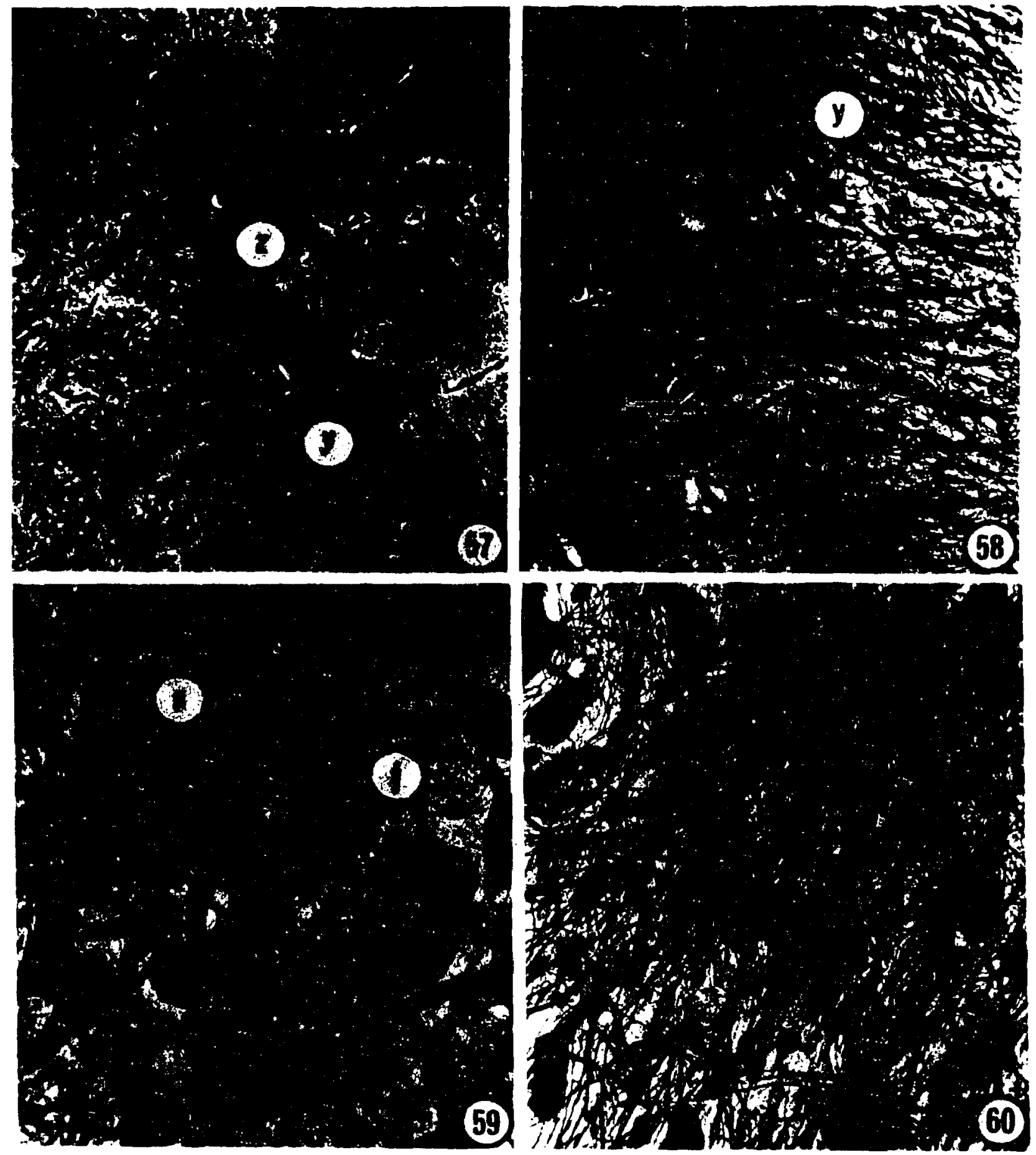
FIg. 61. Monkey. Photomicrograph of the white matter of the precentral gyrus demonstrating thick processes of astrocytes directed toward a vessel wall. $640 \mathrm{X}$

a typical stellate astrocyte

bv blood vessel

p thin processes of an astrocyte

$t$ thick processes of an astrocyte

Fig. 62. Monkey. Photomicrograph of cortical supragranular layers with an astrocyte with fine processes orlented toward a vessel. $500 \mathrm{x}$

bv blood vessel

$p$ thin processes of an astrocyte

Flg. 63. Monkey. Photomicrogreph of an astrocyte with round cell body in the dentate gyrus with a single process specialized for vascular attachment. $400 \mathrm{X}$

bv blood vessel

$t \quad$ thick process of an astrocyte

Fig. 64. Monkey. Photomicrograph of dentate gyrus demonstrating typical astrocytes with round cell bodies. Note specialized process for vascular attachment. $400 \mathrm{X}$

bv blood vessel

$t$ thick process of an astrocyte 
73
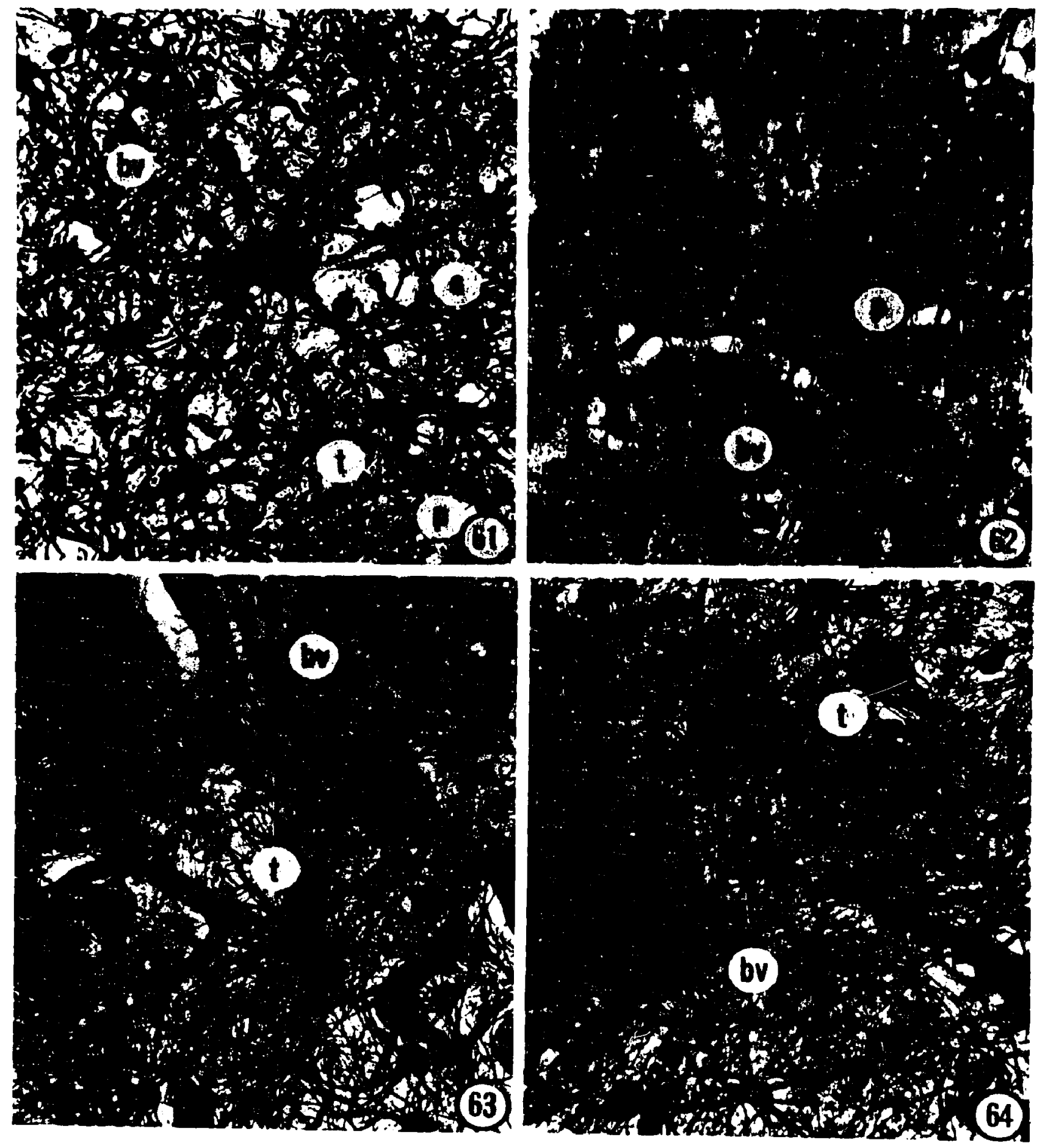